NASA/TM-2009-215595

\title{
The Advanced Noise Control Fan Baseline Measurements
}

Joseph McAllister, Raymond A. Loew, and Joel T. Lauer Sierra Lobo, Inc., Cleveland, Ohio

Daniel L. Sutliff

Glenn Research Center, Cleveland, Ohio 


\section{NASA STI Program . . . in Profile}

Since its founding, NASA has been dedicated to the advancement of aeronautics and space science. The NASA Scientific and Technical Information (STI) program plays a key part in helping NASA maintain this important role.

The NASA STI Program operates under the auspices of the Agency Chief Information Officer. It collects, organizes, provides for archiving, and disseminates NASA's STI. The NASA STI program provides access to the NASA Aeronautics and Space Database and its public interface, the NASA Technical Reports Server, thus providing one of the largest collections of aeronautical and space science STI in the world. Results are published in both non-NASA channels and by NASA in the NASA STI Report Series, which includes the following report types:

- TECHNICAL PUBLICATION. Reports of completed research or a major significant phase of research that present the results of NASA programs and include extensive data or theoretical analysis. Includes compilations of significant scientific and technical data and information deemed to be of continuing reference value. NASA counterpart of peer-reviewed formal professional papers but has less stringent limitations on manuscript length and extent of graphic presentations.

- TECHNICAL MEMORANDUM. Scientific and technical findings that are preliminary or of specialized interest, e.g., quick release reports, working papers, and bibliographies that contain minimal annotation. Does not contain extensive analysis.

- CONTRACTOR REPORT. Scientific and technical findings by NASA-sponsored contractors and grantees.
- CONFERENCE PUBLICATION. Collected papers from scientific and technical conferences, symposia, seminars, or other meetings sponsored or cosponsored by NASA.

- SPECIAL PUBLICATION. Scientific, technical, or historical information from NASA programs, projects, and missions, often concerned with subjects having substantial public interest.

- TECHNICAL TRANSLATION. Englishlanguage translations of foreign scientific and technical material pertinent to NASA's mission.

Specialized services also include creating custom thesauri, building customized databases, organizing and publishing research results.

For more information about the NASA STI program, see the following:

- Access the NASA STI program home page at http://www.sti.nasa.gov

- E-mail your question via the Internet to help@ sti.nasa.gov

- Fax your question to the NASA STI Help Desk at $443-757-5803$

- Telephone the NASA STI Help Desk at 443-757-5802

- Write to: NASA Center for AeroSpace Information (CASI) 7115 Standard Drive Hanover, MD 21076-1320 
NASA/TM-2009-215595

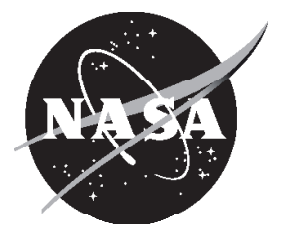

\section{The Advanced Noise Control Fan Baseline Measurements}

Joseph McAllister, Raymond A. Loew, and Joel T. Lauer

Sierra Lobo, Inc., Cleveland, Ohio

Daniel L. Sutliff

Glenn Research Center, Cleveland, Ohio

Prepared for the

47th Aerospace Sciences Meeting

sponsored by the American Institute of Aeronautics and Astronautics

Orlando, Florida, January 5-8, 2009

National Aeronautics and

Space Administration

Glenn Research Center

Cleveland, Ohio 44135 
This work was sponsored by the Fundamental Aeronautics Program at the NASA Glenn Research Center.

Level of Review: This material has been technically reviewed by technical management.

Available from

NASA Center for Aerospace Information

7115 Standard Drive

Hanover, MD 21076-1320
National Technical Information Service 5285 Port Royal Road Springfield, VA 22161

Available electronically at $\underline{\mathrm{http}: / / g l t r s . g r c . n a s a . g o v}$ 


\title{
The Advanced Noise Control Fan Baseline Measurements
}

\author{
Joseph McAllister, Raymond A. Loew, and Joel T. Lauer \\ Sierra Lobo, Inc. \\ Cleveland, Ohio 44135 \\ Daniel L. Sutliff \\ National Aeronautics and Space Administration \\ Glenn Research Center \\ Cleveland, Ohio 44135
}

\begin{abstract}
The NASA Glenn Research Center's (NASA Glenn) Advanced Noise Control Fan (ANCF) was developed in the early 1990s to provide a convenient test bed to measure and understand fan-generated acoustics, duct propagation, and radiation to the farfield. As part of a complete upgrade, current baseline and acoustic measurements were documented herein. Extensive in-duct, farfield acoustic, and flow field measurements are reported for a variety of configurations. This paper is a follow on to an earlier paper describing the operation of the ANCF.
\end{abstract}

\section{Introduction}

The NASA Glenn Research Center (NASA Glenn) has been involved in several programs (Advanced Subsonic Technology, Quiet Aircraft Technology, and the Fundamental Aeronautics Subsonic Fixed Wing) whose goals were the reduction in transport aircraft noise attributed to the turbofan engine. A component of turbofan noise (Ref. 1) is the fan noise caused by rotor-stator, and other interactions, coupled to duct propagation that radiates to the farfield. The Advanced Noise Control Fan (Ref. 2) (ANCF) test bed was built in the early 1990s (Refs. 3 and 4) to evaluate noise reduction concepts and to provide a database for Computational Aero-Acoustic (CAA) code verification. In 2008, the ANCF fan blades and ICD were upgraded prompting the need for an updated baseline acoustic and aerodynamic performance database. These measurements are reported in this paper to present information relevant to potential usage of the ANCF for noise reduction, code verification, and/or measurement system evaluation.

The ANCF is a highly configurable 4- $\mathrm{ft}$ diameter ducted fan located in the Aero-Acoustic Propulsion Laboratory (Ref. 5) (AAPL) at NASA Glenn. The AAPL is a hemispherical anechoic (above $125 \mathrm{~Hz}$ ) test facility used for noise measurements. An exterior view of the 65-ft-high dome is shown in Figure 1 . The ANCF, shown in Figure 2, operates inside an enclosed, compact, farfield arena designed (Ref. 6) such that it is in an anechoic environment. This allows for the continual acquisition of farfield data without moving the rig, or impacting the overall productivity of the other AAPL test rigs.

The nominal operating condition of the ANCF is 1800 revolutions-per-minute-corrected (rpmc) resulting in a tip speed of $375 \mathrm{ft} / \mathrm{sec}$, an inlet duct Mach number of $\sim 0.15$, and a fundamental blade passing frequency (BPF) of $\sim 500 \mathrm{~Hz}$. The fan speed can vary from 100 to $2400 \mathrm{rpmc}$. The ANCF can be run rotor alone, and the pitch of the 16 fan blades (B), nominally $28^{\circ}$, can be adjusted to $18^{\circ}$ or $38^{\circ}$. A variable count stator hub is attached to the center-body downstream of the fan to test rotor/stator interaction conditions. Stator counts can vary and can be set at any angle. Inlet flow disturbances can be simulated using circumferentially distributed radially-extended rods installed in front of the rotor.

It is not the intent of this paper to provide in-depth analysis of the aero-acoustic data but rather to provide a general description of the range of data available. Databases can be made upon request.

The reader may refer to the Appendix throughout the paper for orientation. Figure A1 shows a flow chart of the aero-acoustics physics and measurement philosophy. Figure A2 presents a three-dimensional line drawing of the ANCF in the AAPL. 


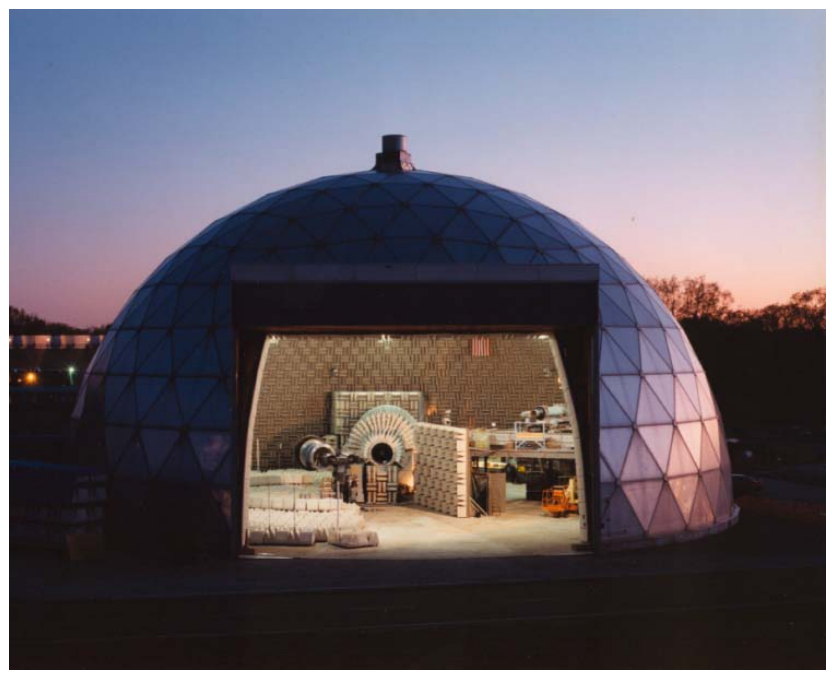

Figure 1.-Aero-Acoustic Propulsion Laboratory (AAPL).

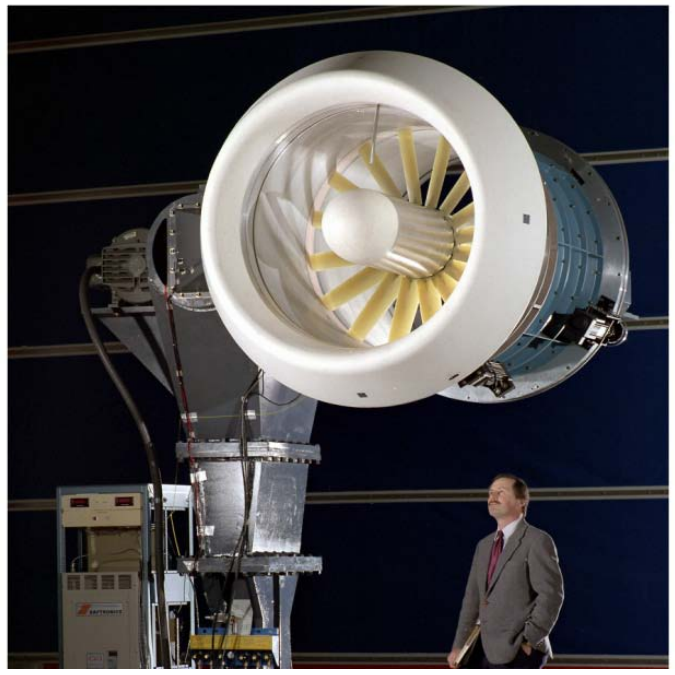

Figure 2.-Advanced noise control fan.

TABLE I.-CONFIGURATIONS TESTED

[All were $200 \mathrm{rpmc}$ increments.]

\begin{tabular}{|l|c|c|c|c|c|}
\hline \multicolumn{1}{|c|}{$\begin{array}{c}\text { Fan } \\
\text { configuration }\end{array}$} & $\begin{array}{c}\text { Farfield } \\
\text { directivity, } \\
\text { rpmc }\end{array}$ & $\begin{array}{c}\text { Rotating rake } \\
\text { modes, } \\
\text { rpmc }\end{array}$ & $\begin{array}{c}\text { Vane unsteady } \\
\text { pressures, } \\
\text { rpmc }\end{array}$ & $\begin{array}{c}\text { Hotfilm } \\
\text { traverses, } \\
\text { rpmc }\end{array}$ & $\begin{array}{c}\text { Steady pressure } \\
\text { traverses, } \\
\text { rpmc }\end{array}$ \\
\hline Rotor alone & 1400 to 2000 & 1400 to 2000 & none & 1800 & 1800 \\
\hline 14 vanes at 1/2C & 1400 to 2000 & 1400 to 2000 & 1400 to 2000 & none & none \\
\hline 14 vanes at 1C & 1400 to 2000 & 1400 to 2000 & 1400 to 2000 & 1800 & 1800 \\
\hline 28 vanes at 1C & 1400 to 2000 & 1400 to 2000 & none & none & none \\
\hline 13 vanes at 1C & 1400 to 2000 & 1400 to 2000 & none & none & none \\
\hline 26 vanes at $1 C$ & 1400 to 2000 & 1400 to 2000 & none & none & none \\
\hline
\end{tabular}

\section{Test Conditions}

Baseline data were acquired over a corrected fan speed range of 1400 to $2000 \mathrm{rpmc}$. Acoustic farfield directivity, and Rotating Rake (Ref. 7) inlet and exhaust duct mode data were acquired at $200 \mathrm{rpmc}$ increments. These acoustic baseline measurements were acquired in several ANCF configurations: Rotor alone (no stator vanes), 14 stator vanes at 1/2-chord spacing; 13, 14, 26, and 28 stator vanes at 1-chord spacing. Stator-vane spacing is defined as the distance between the rotor blade trailing edge and the stator-vane leading edge, at the hub, divided by the stator-vane chord dimension ( 5 in.). Stator-vane unsteady surface pressures were acquired during the 14-vane configurations.

Flow measurement radial traverses using a 2-component hot-film probe, a static pressure probe, and a total pressure probe, were acquired at several axial duct locations at a corrected fan speed of $1800 \mathrm{rpmc}$. These measurements were taken in the rotor alone and with 14 vanes at 1 chord spacing.

Detailed descriptions of measurement systems are provided in Reference 1. Table I provides the test conditions and data sets obtained.

\section{Results}

\section{Acoustic Measurements}

\section{Farfield}

Farfield acoustic directivities were acquired using 30 microphones placed at a 12 -ft radius from the duct centerline and $10 \mathrm{ft}$ high. Fifteen of these were in an arc about the inlet exit plane $\left(0^{\circ}\right.$ to $90^{\circ}$ measured from the inlet axis) and 15 were in an arc about the exhaust exit plane $\left(90^{\circ}\right.$ to $165^{\circ}$ with $180^{\circ}$ 


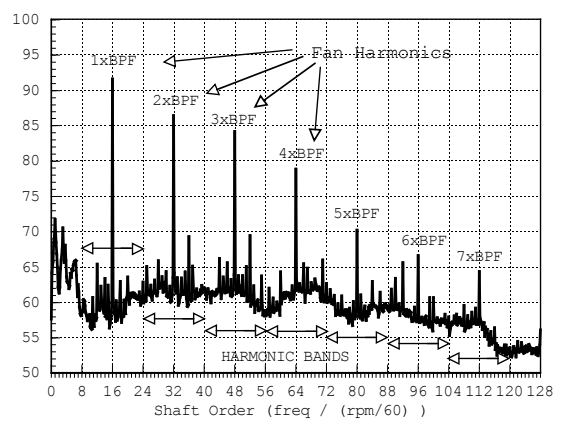

(a) Original spectral sample

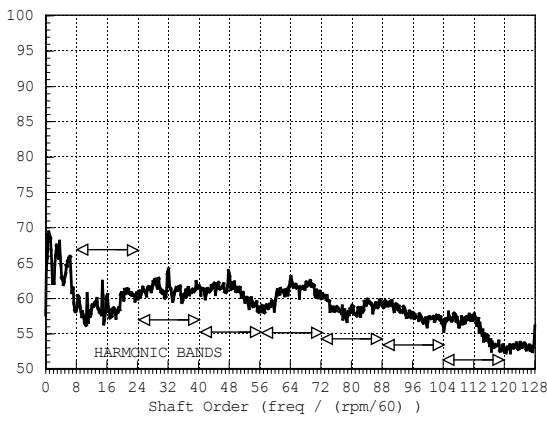

(b) Spectral sample with fan harmonics removed

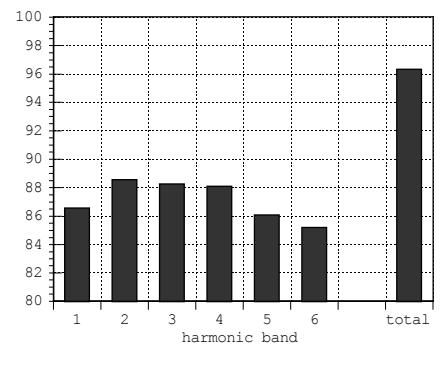

1st harmonic band : integrate $8-24$ shaft orders 2nd harmonic band : integrate $24-40$ shaft orders

3rd harmonic band : integrate 40-56 shaft orders

(c) Harmonic bands

Figure 3.-Example of farfield data reduction into harmonic bands.

being the exhaust axis). Reference 2 presented diagrams of the array locations. The time histories are processed using ensemble averaging in order to analyze the tonal and broadband components separately by extracting the tones generated by the fan (shaft orders and harmonics). This can be done exactly since the data are acquired synchronously to the shaft rotation. The data is also broken down and analyzed by frequency bands. The 1st harmonic band is defined as the integration about the 1st fan harmonic or from 0.5 to $1.5 \mathrm{~B}$; the 2 nd harmonic band from 1.5 to $2.5 \mathrm{~B}$, etc. - where $\mathrm{B}$ is the number of blades, so the $1 \mathrm{st}$ harmonic band is centered on 16 shaft orders and is the integration from 8 to 24 shaft orders (Fig. 3). The original time histories and the extracted broadband are each analyzed in this manner. The fan harmonics are simply "picked" off the spectra. The data can then be converted to Power Level (PWL) by squaring the pressure and multiplying by the appropriate area, then normalizing by specific acoustic impedance. Thus each farfield acoustic data run can be reduced to overall, broadband, and tonal power components.

Figure 4 shows the farfield directivity with 14 stator vanes installed at spacings of 1 - and 1/2 -chord compared to rotor alone, at a speed of $1800 \mathrm{rpmc}$. The tonal directivity of the $1 \mathrm{st}$ three fan harmonics are in sub-plots (a), (b), and (c). The lobed-nature of tone propagation is clearly seen. The broadband directivity of the 1 st three fan harmonics are in sub-plots (d), (e), and (f). The strong $+20 \mathrm{~dB}$ and lobednature of tone propagation is clearly seen. A small increase (1 to $2 \mathrm{~dB}$ ) in the broadband noise is seen. The "tail-up" at $165^{\circ}$ with the rotor alone (0 vanes) is due to residual swirl widening the exhaust -plume generating wind noise on that microphone.

Figures 5 to 7 show the farfield directivity generated with 28, 13, and 26 vanes at 1-chord spacing, at a speed of $1800 \mathrm{rpmc}$. The rotor-alone directivity is retained for comparison. The anomalous point in the rotor alone speed line for the BPF aft arc at a speed of $1600 \mathrm{rpmc}$, is due to the foam wind screen being blown off the last 2 microphones. The high-vane counts result in the 1st BPF cut-off (Ref. 8), hence the very small tone levels measured at BPF as seen in Figures 5(a) and 7(a).

The tonal and broadband directivities are each integrated over the forward and aft farfield arcs to obtain total tonal and broadband power (PWL) versus rpmc. These results are plotted in Figures 8 to 11 . The 1st three fundamental fan-tone components are presented respectively in sub-plots (a), (b), and (c); the 1st three harmonic components are presented in sub-plots (d), (e), and (f). A general increase in PWL versus RPMc is expected and seen. 

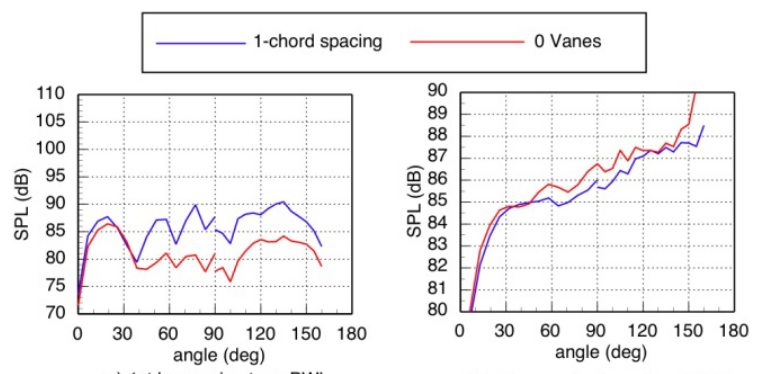

a) 1st harmonic - tone PWL
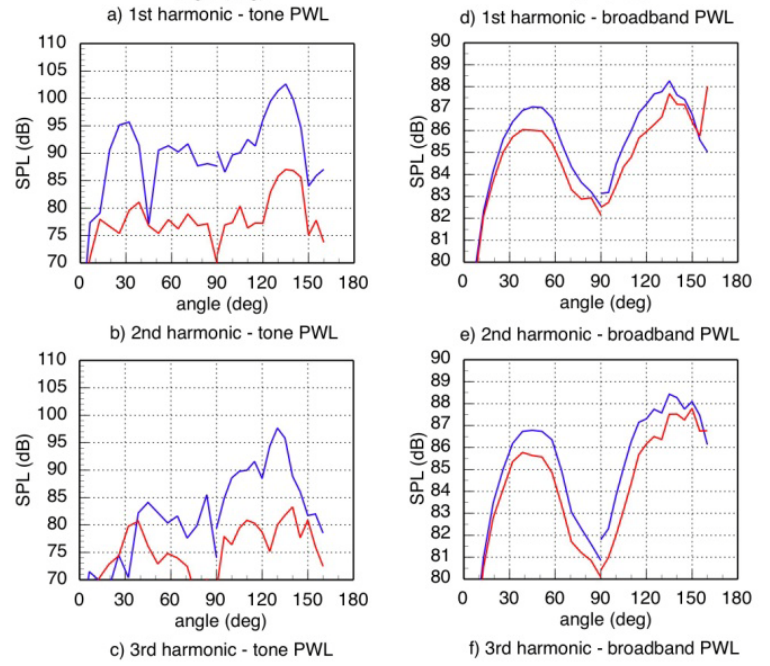

Figure 4.-Directivities with 14 vanes installed.
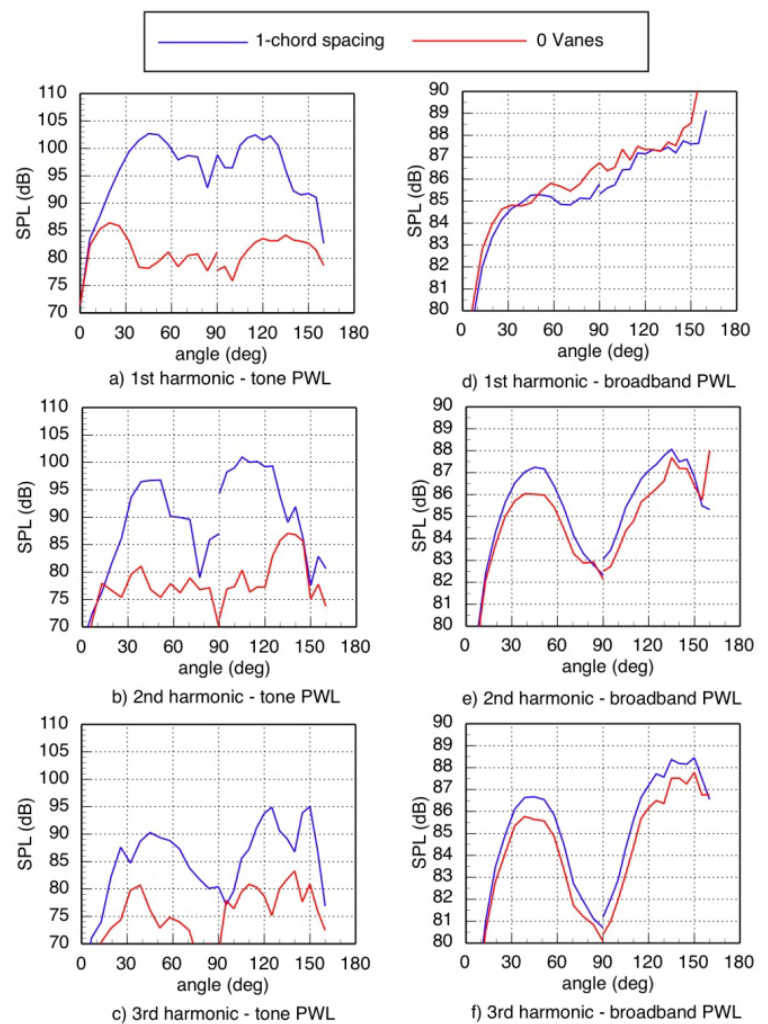

Figure 6.-Directivities with 13 vanes installed.
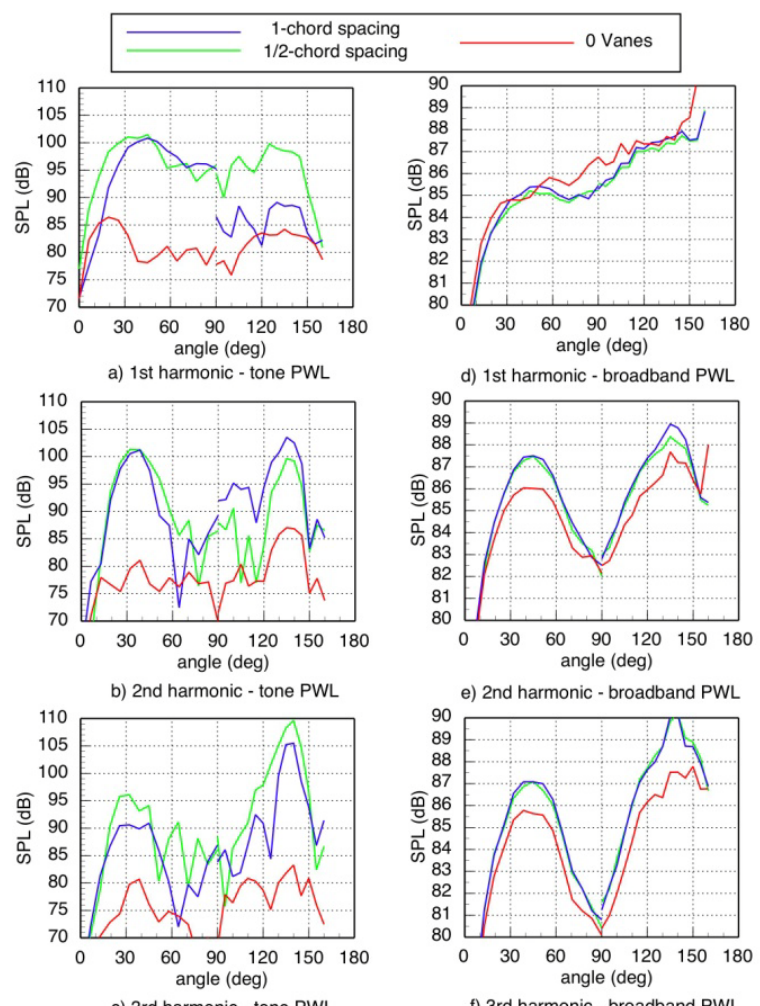

f) 3rd harmonic - broadband PWL

Figure 5.-Directivities with 28 vanes installed.
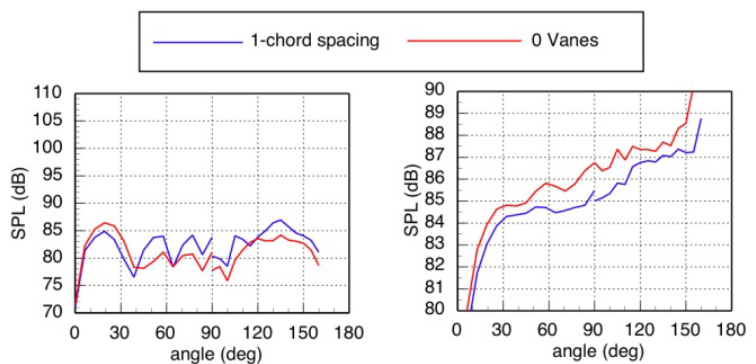

a) 1st harmonic - tone PWL
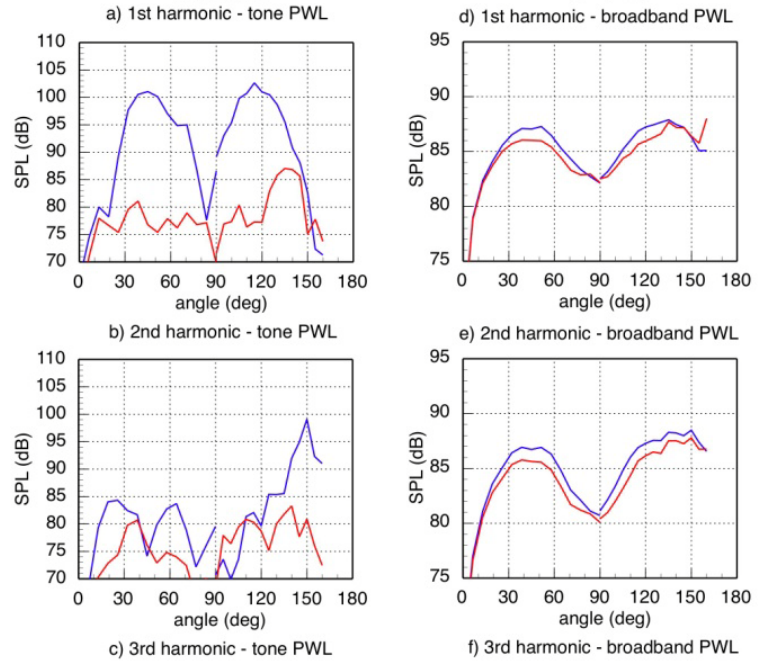

Figure 7.-Directivities with 26 vanes installed 

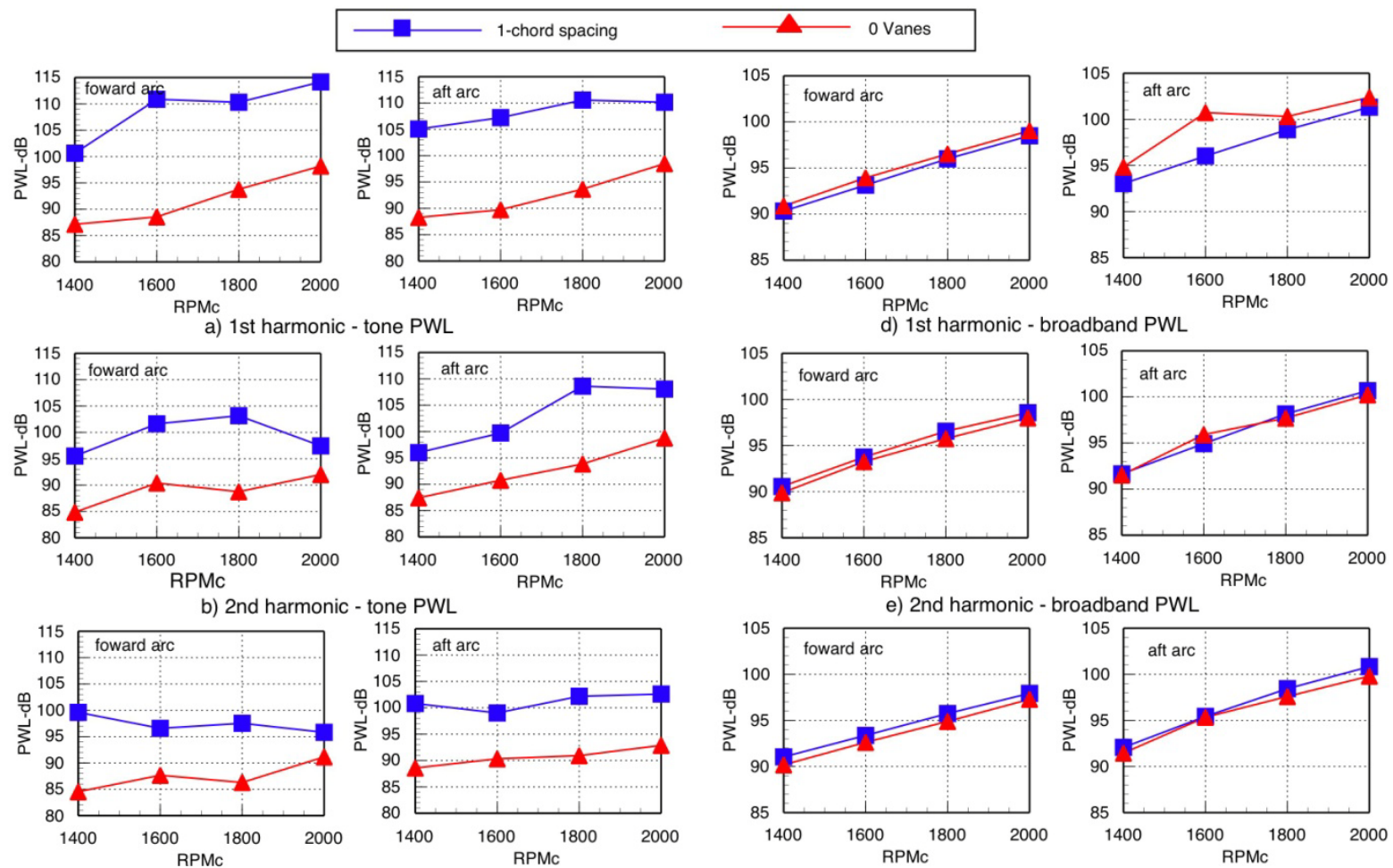

c) 3rd harmonic - tone PWL
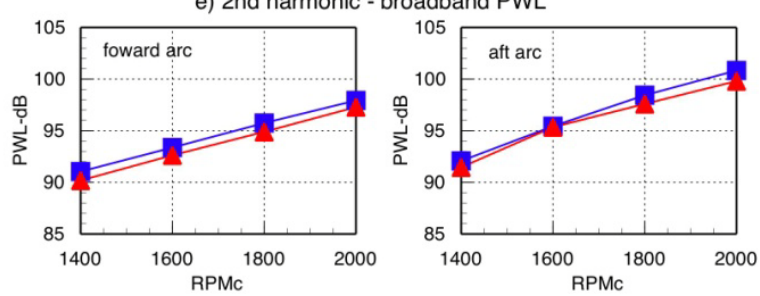

f) 3rd harmonic - broadband PWL

Figure 8.-PWLs versus rpm with 14 vanes installed compared to rotor alone.
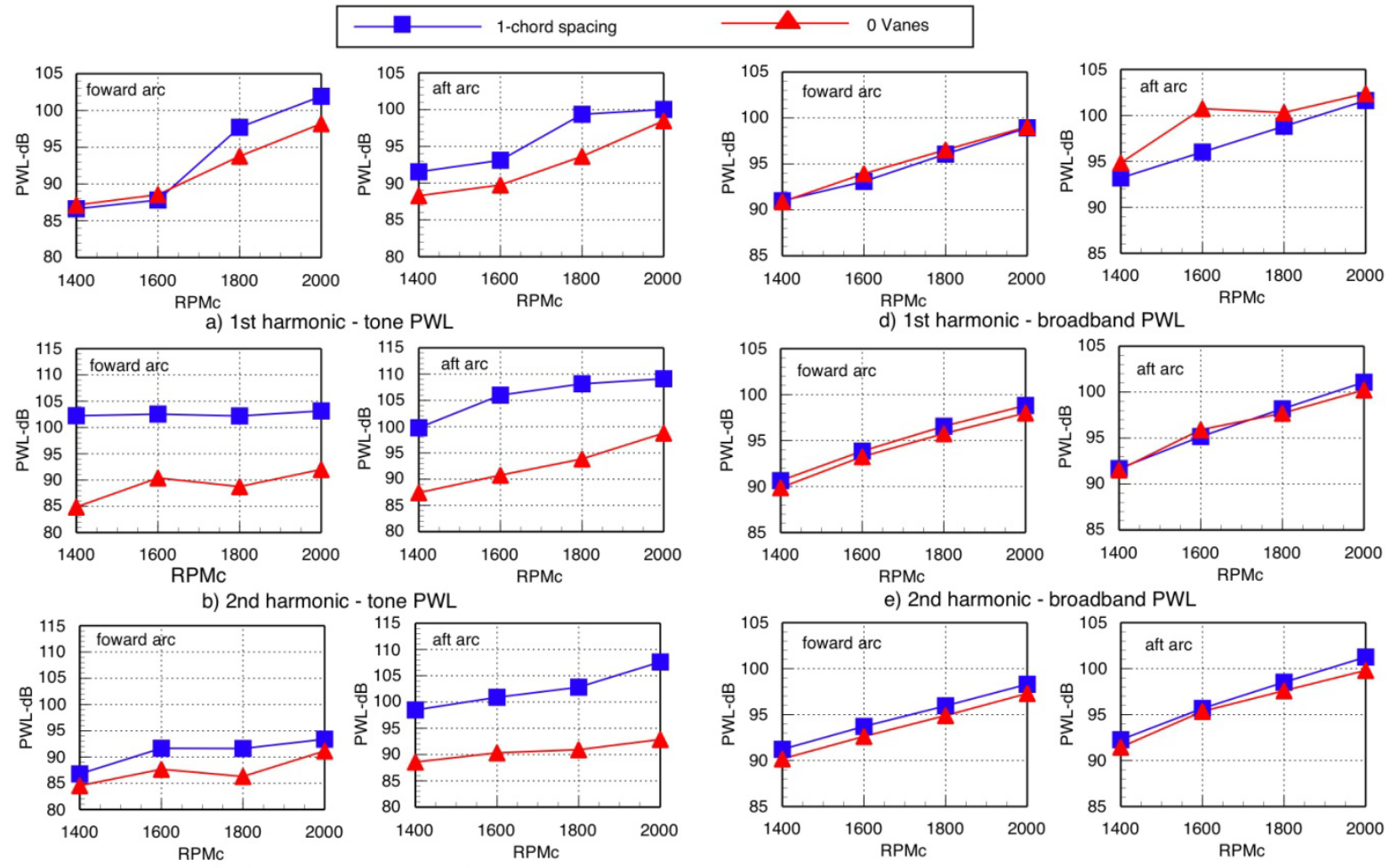

c) 3rd harmonic - tone PWL

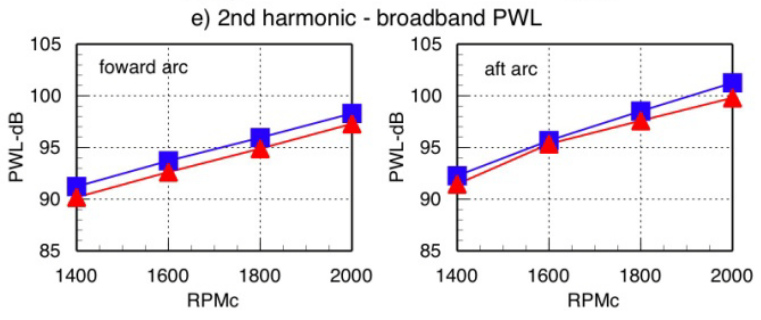

f) 3rd harmonic - broadband PWL

Figure 9.-PWLs versus rpm with 28 vanes installed compared to rotor alone. 

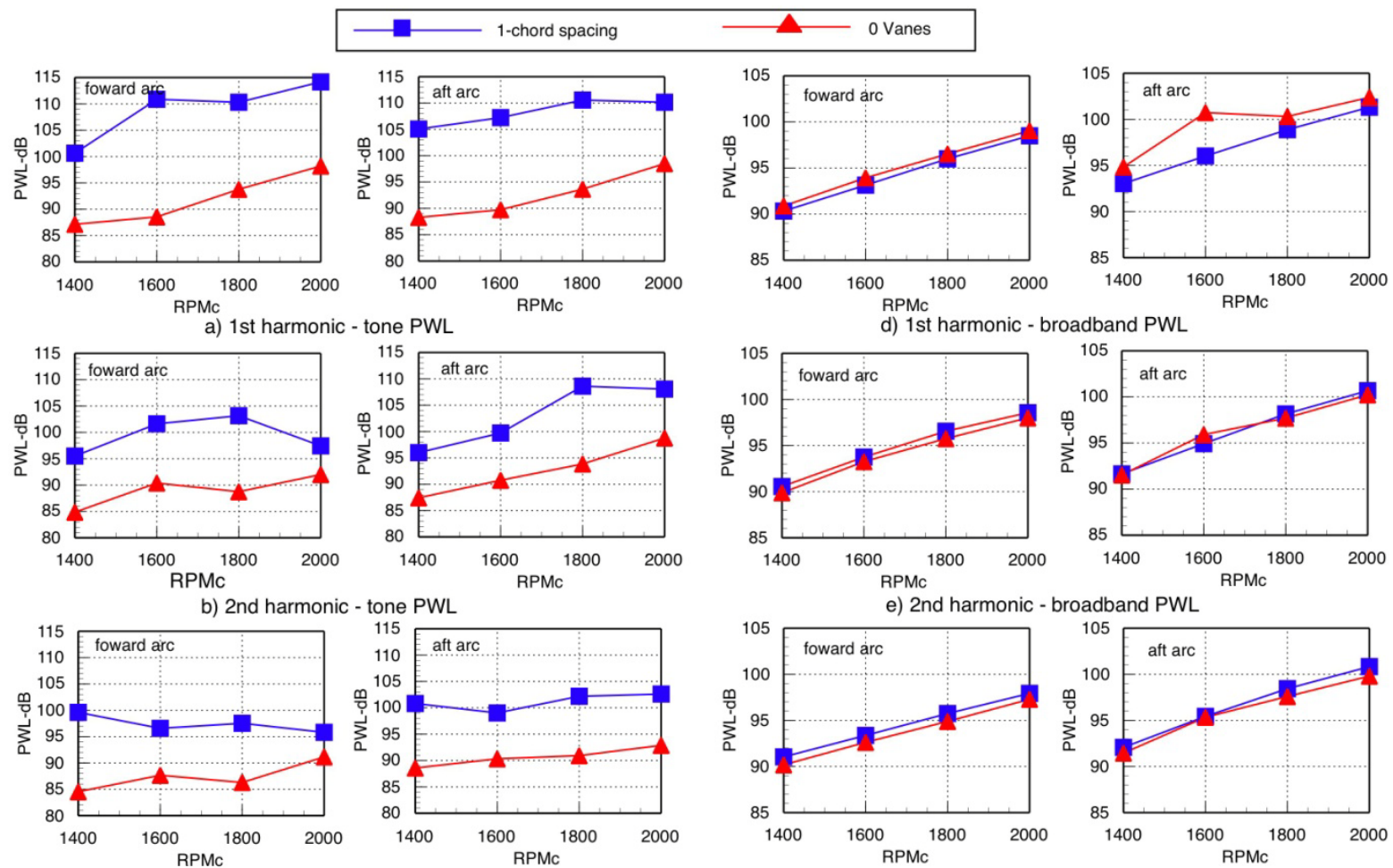

c) 3rd harmonic - tone PWL
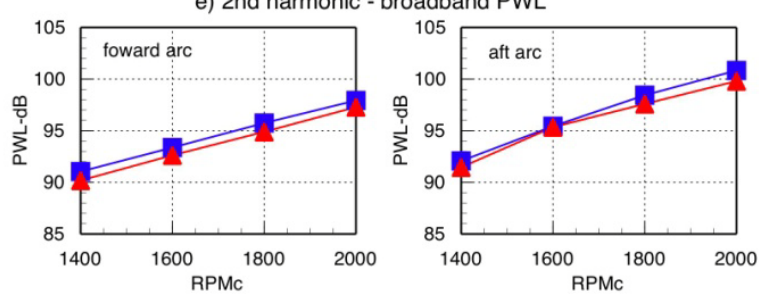

f) 3rd harmonic - broadband PWL

Figure 10.-PWLs versus rpm with 13 vanes installed compared to rotor alone.
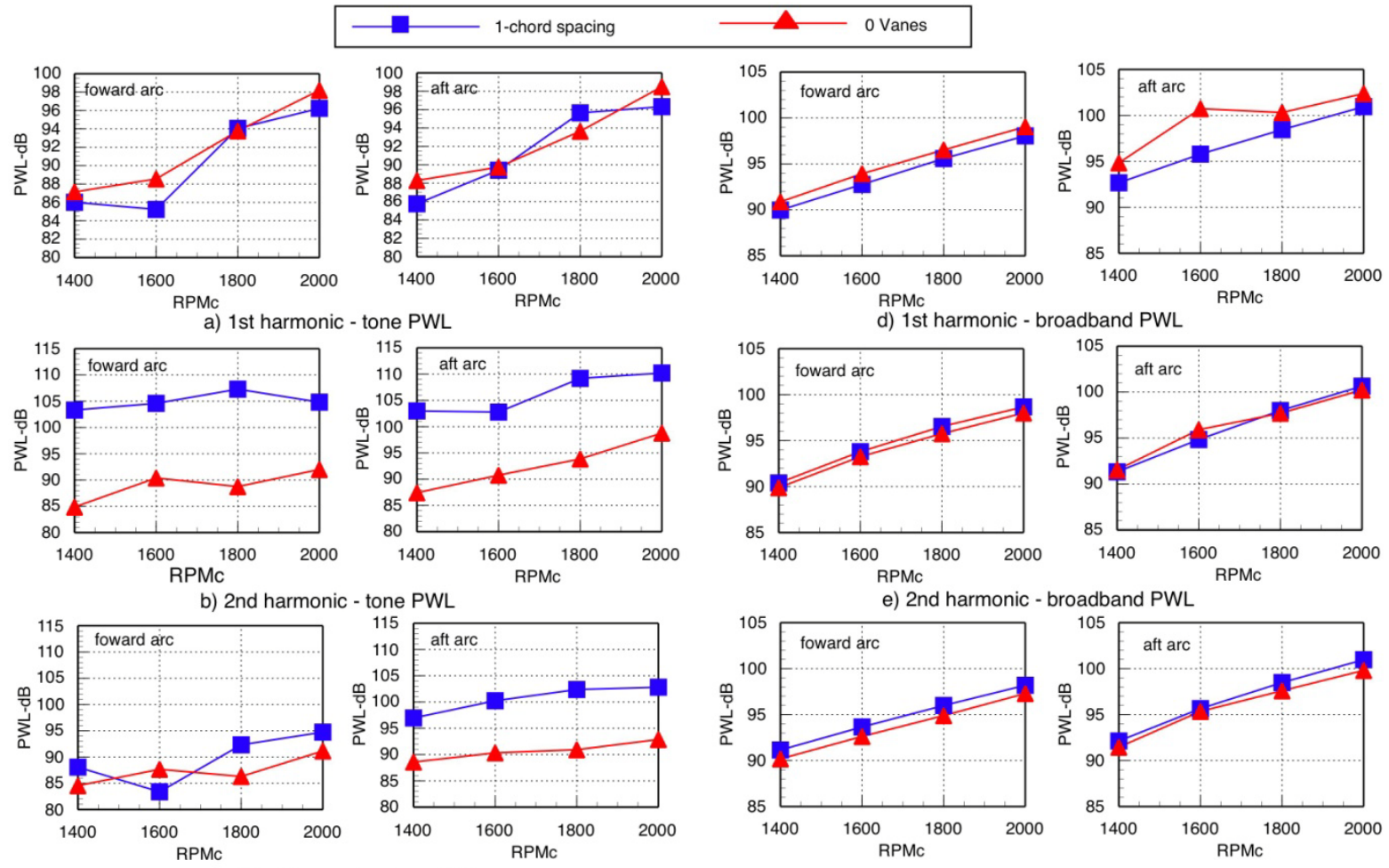

c) 3rd harmonic - tone PWL
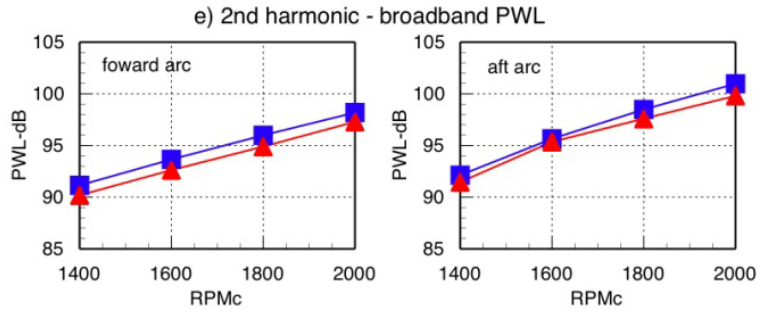

f) 3rd harmonic - broadband PWL

Figure 11.-PWLs versus rpm with 26 vanes installed compared to rotor alone. 


\section{Duct Modes}

The in-duct modal data propagating in the inlet and exhaust ducts were acquired at the configurations/conditions listed in Table I using modal theory as described in the classic reference paper by Tyler-Sofrin (Ref. 9) and first implemented at NASA GRC (Ref. 10). The vane counts presented were chosen to illustrate the basic concepts of modal-generation and propagation.

The modal data from the rotating rake are presented in three-dimensional format. The base plane axes are circumferential (m) and radial (n) order, and the vertical value axis is the PWL in the $(\mathrm{m}, \mathrm{n})$ mode. Along the wall of the m-order axis the sum of all the radials provides the power in that circumferential mode. The sum of all circumferential modes provides the PWL in the harmonic presented. The measurement noise floor is generally the lowest level present on the vertical axis. Only modes that can possibly propagate based on fan frequency and duct geometry are plotted, giving the plot the distinctive triangle-shape of propagating modes. A typical modal decomposition provides information as to the dominant modes present, usually those due to the rotor-stator interaction. Of secondary interest will be other modes, which may be due to inflow distortions or other geometric disturbances. Tabulated on each plot is the PWL in the expected rotor-stator interaction mode(s) and the total PWL in the fan harmonic.

Figures 12 to 16 show the modal decompositions in the inlet/exhaust for the $1 \mathrm{st}(\mathrm{a} / \mathrm{b}), 2 \mathrm{nd}(\mathrm{c} / \mathrm{d})$, and 3rd (e/f) fan harmonics. The low vane counts (Figs. 13 and 14) show a single positive rotor-stator interaction mode as predicted by the Tyler-Sofrin theory. The high vane count configurations (Figs. 26 and 28) show the nearly nonexistent modal presence at BPF, as this is the cut-off condition. As the harmonic increases the presence of additional interaction modes are measured.

The rotor-stator interaction modes are plotted versus rpmc in Figures 17 to 20. The expected BPF radial modes measured in the inlet are presented in (a) and for the exhaust, (b). The 2BPF interaction modes are presented in (c) and (d). The $+m$ (rotating with the fan) are plotted in (e) inlet, and (f) exhaust; and $-\mathrm{m}$ (rotating against the fan) are plotted in $(\mathrm{g})$ inlet, and $(\mathrm{h})$ exhaust.

As can be seen in both the three-dimensional and the speed-plots, the + m-orders are generally higher than the $-\mathrm{m}$-orders due to the expected rotor transmission loss. 

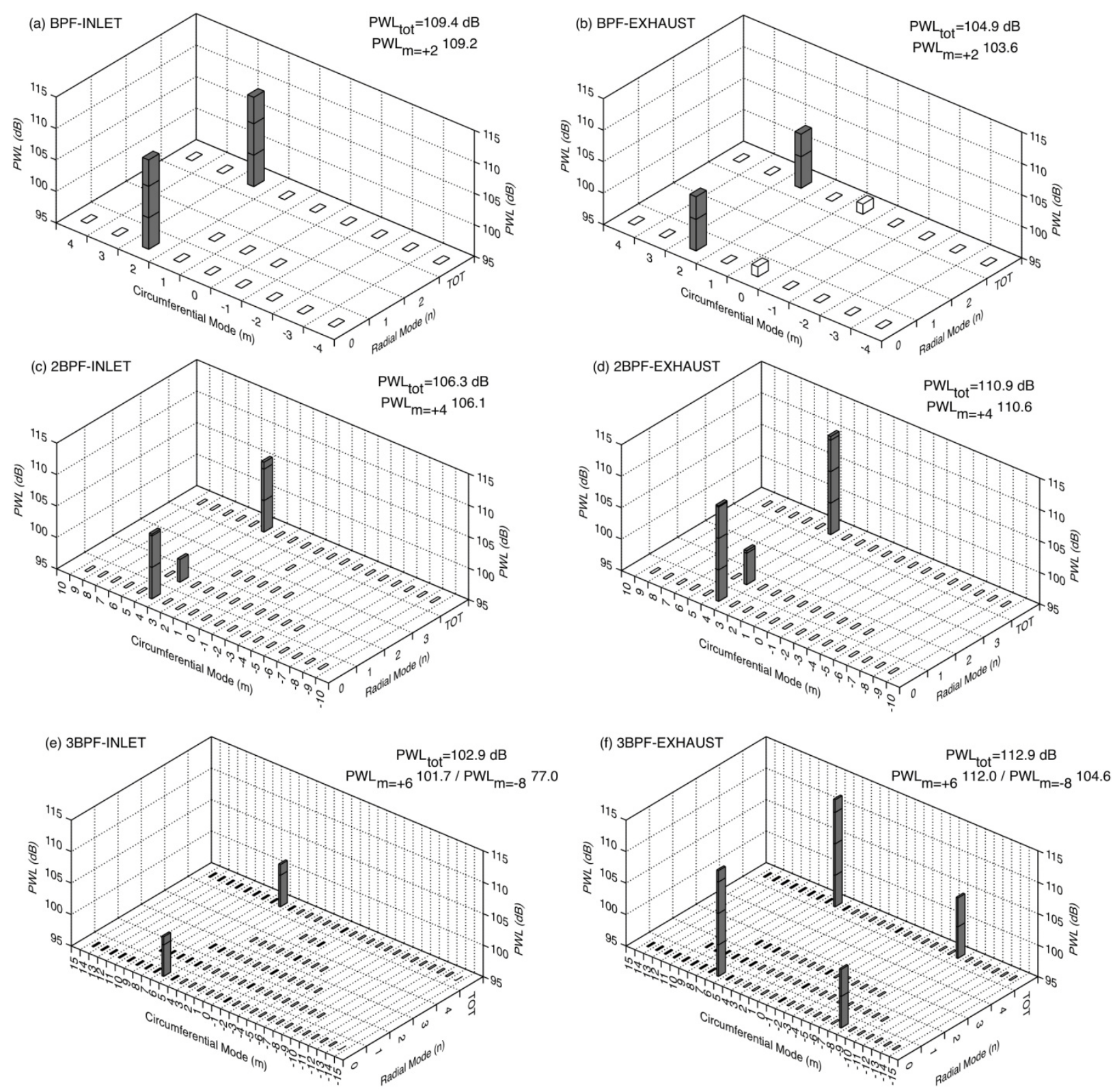

Figure 12.-Modal plots with 14 stator vanes at 1-chord; 1800 rpmc. 

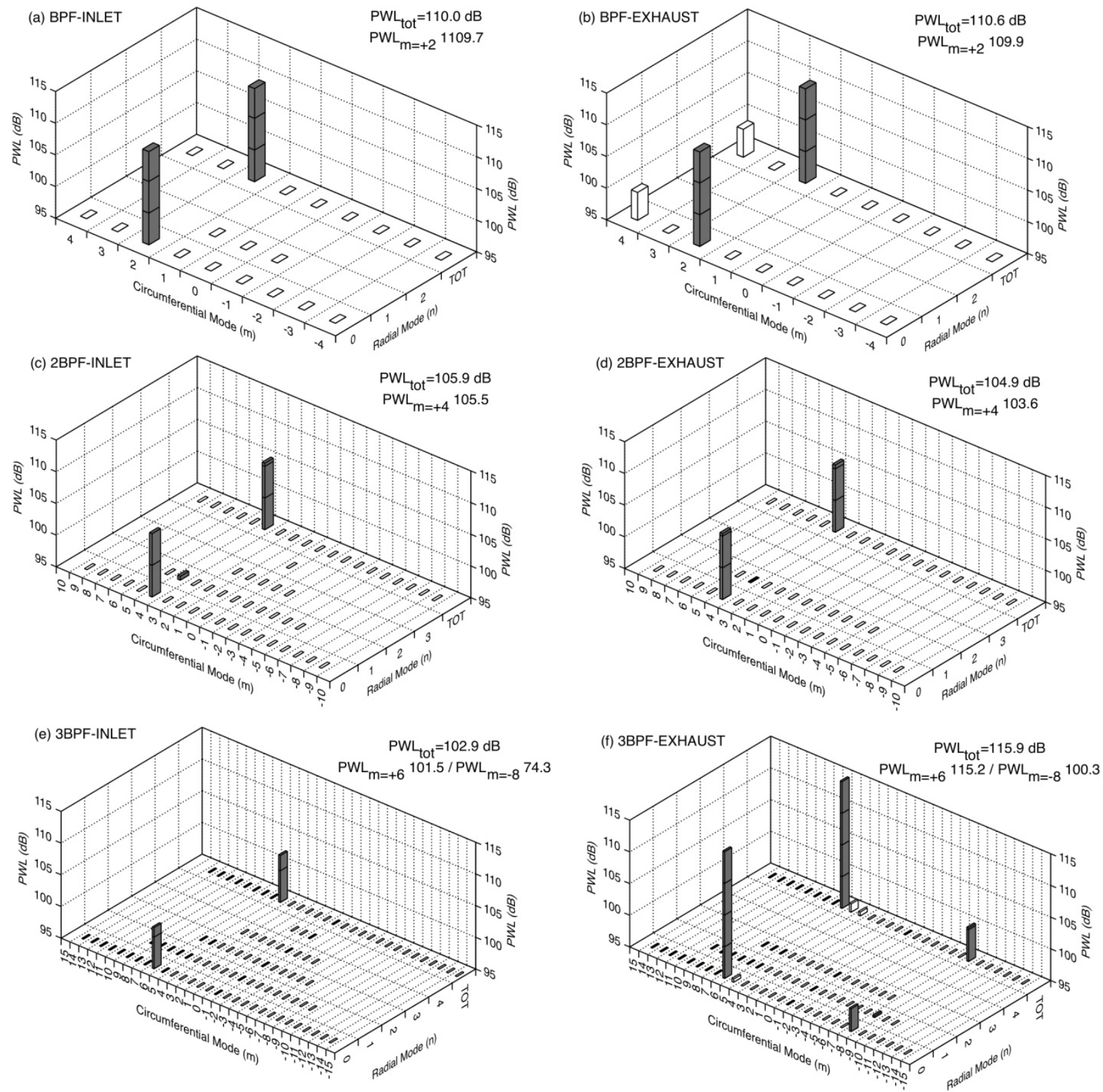

Figure 13.-Modal plots with 14 stator vanes at 1/2-chord; $1800 \mathrm{rpmc}$. 

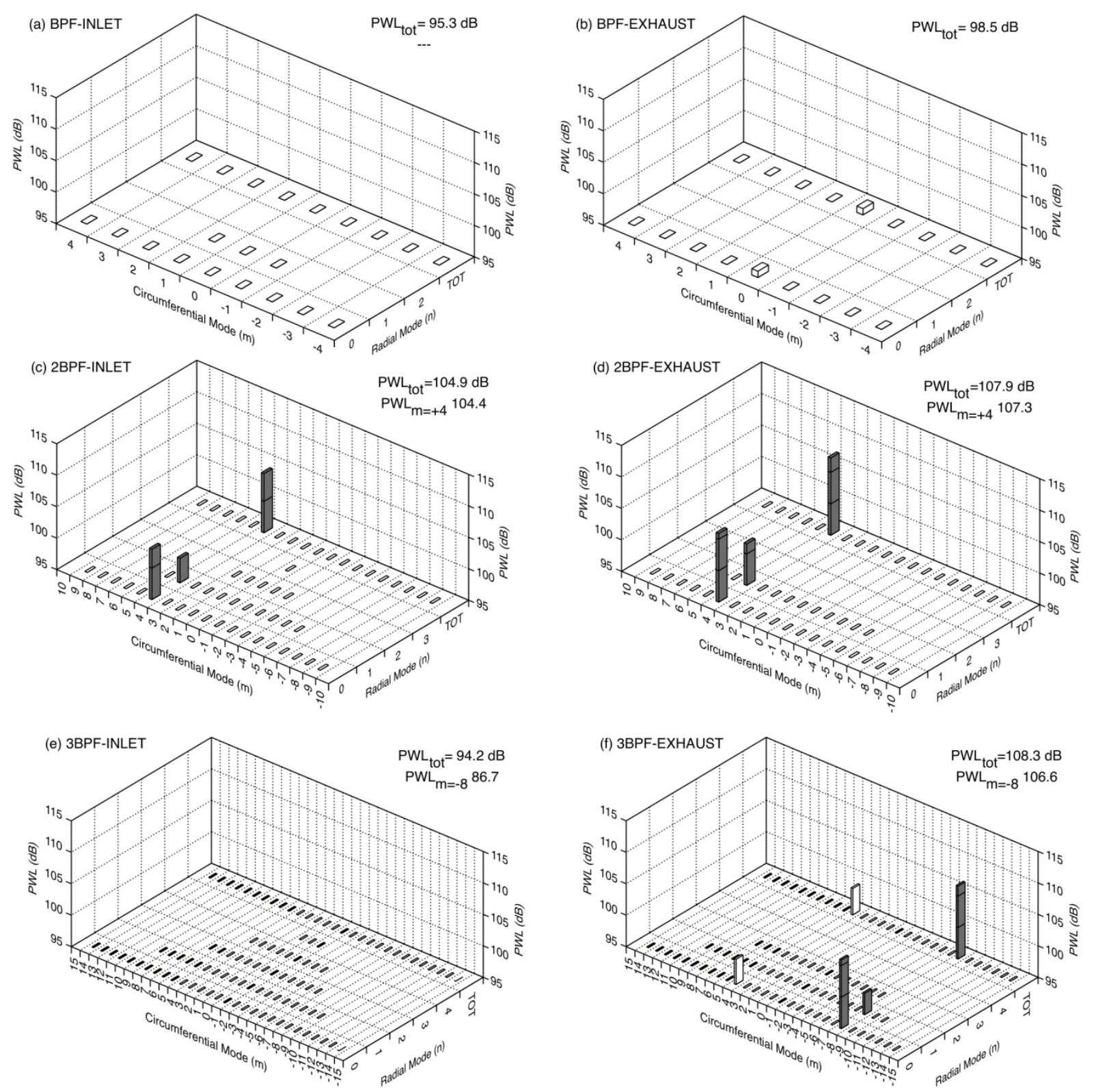

Figure 14.-Modal plots with 28 stator vanes at 1-chord; 1800 rpmc. 

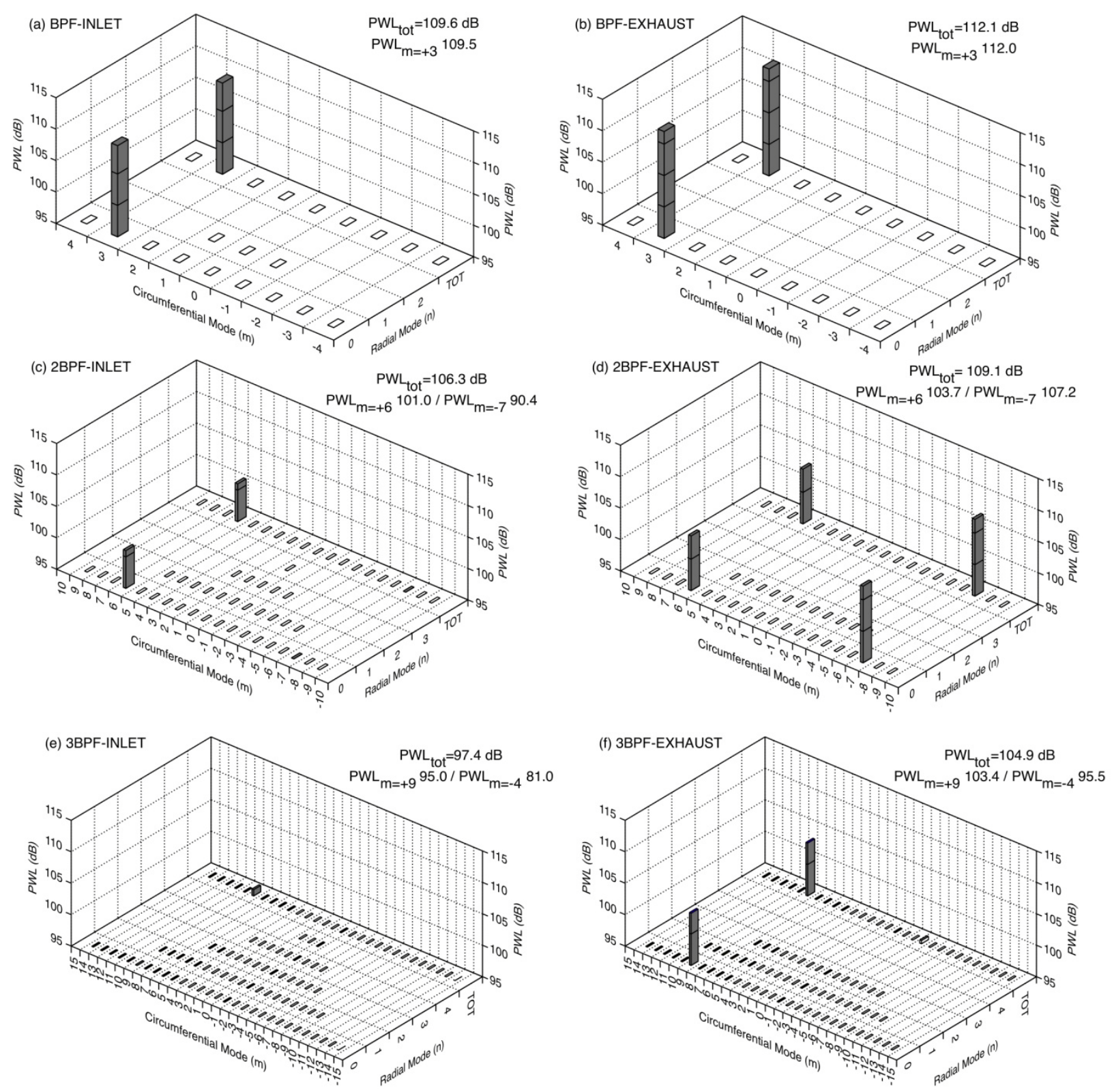

Figure 15.-Modal plots with 13 stator vanes at 1 -chord; $1800 \mathrm{rpmc}$. 

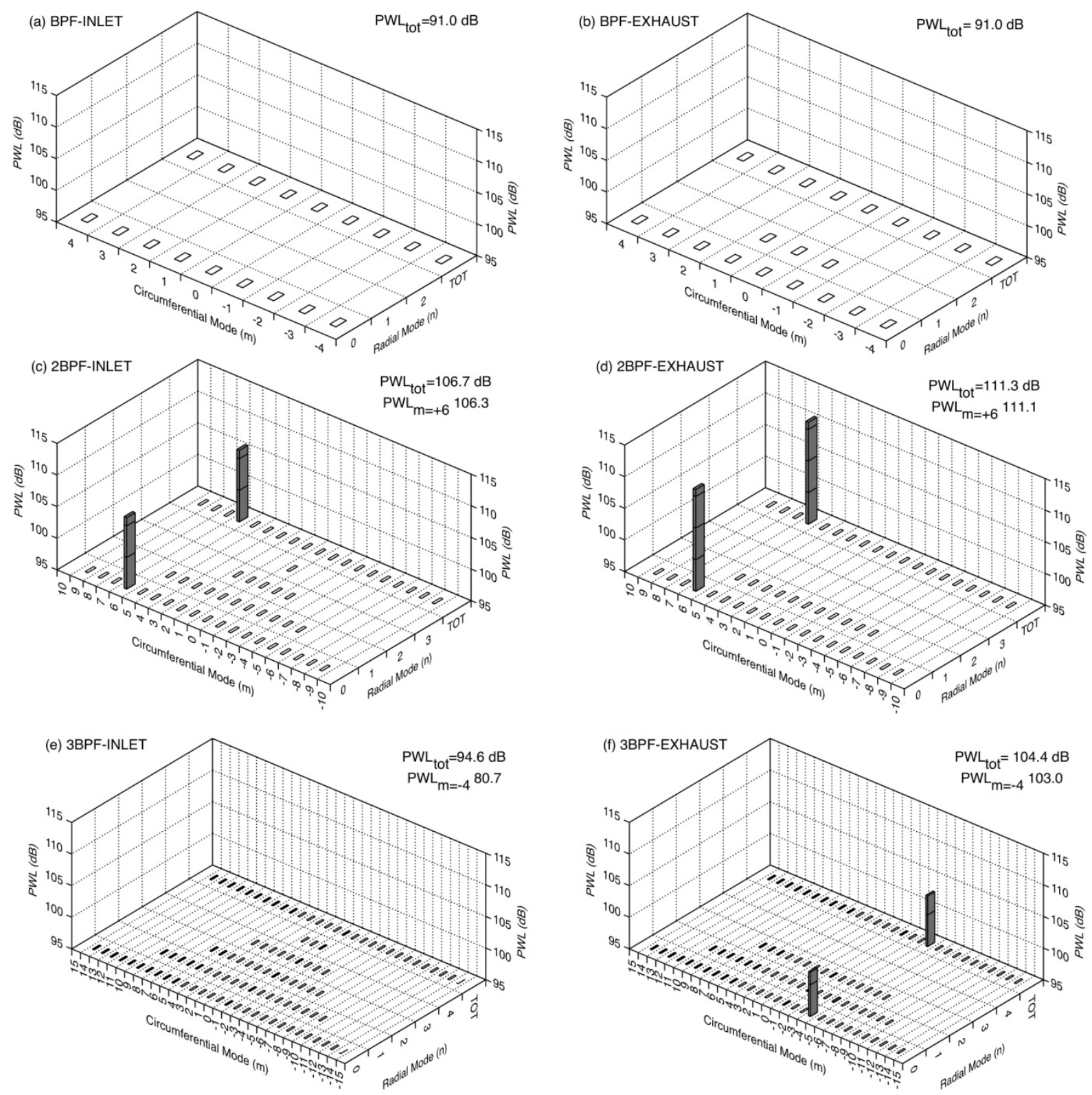

Figure 16.-Modal plots with 26 stator vanes at 1-chord; 1800 rpmc. 


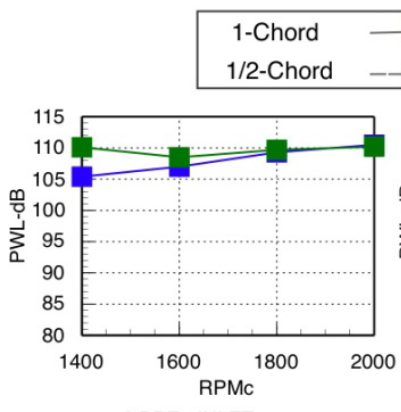

a) BPF - INLET
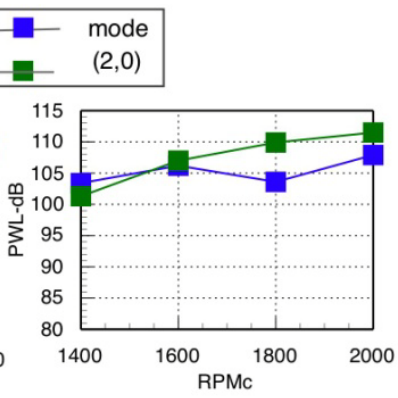

b) BPF - EXHAUST

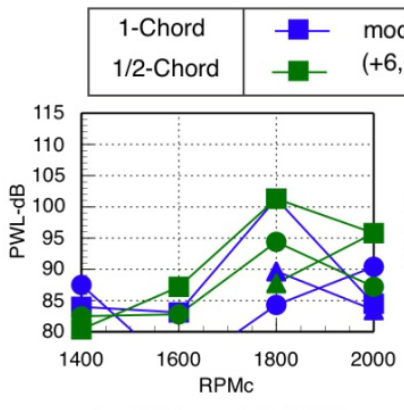

e) $3 \times B P F(+m$ order $)$ INLET
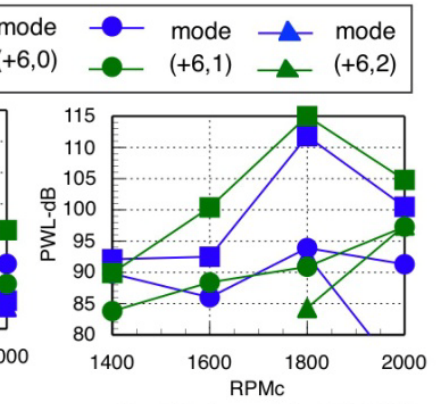

f) 3XBPF (+m order) - EXHAUST

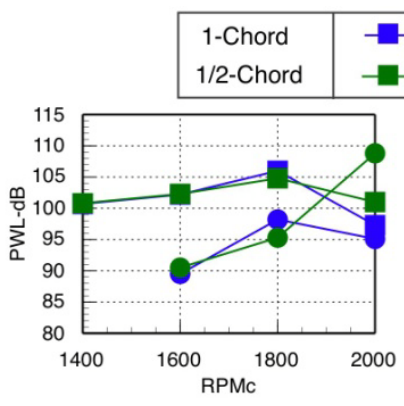

c) $2 \times B P F$ - INLET
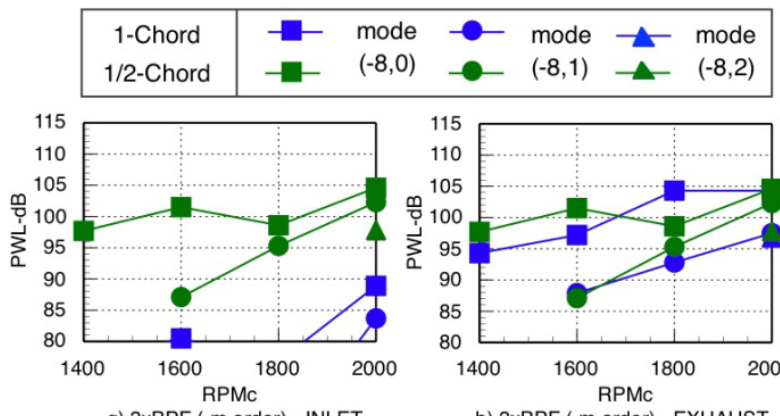
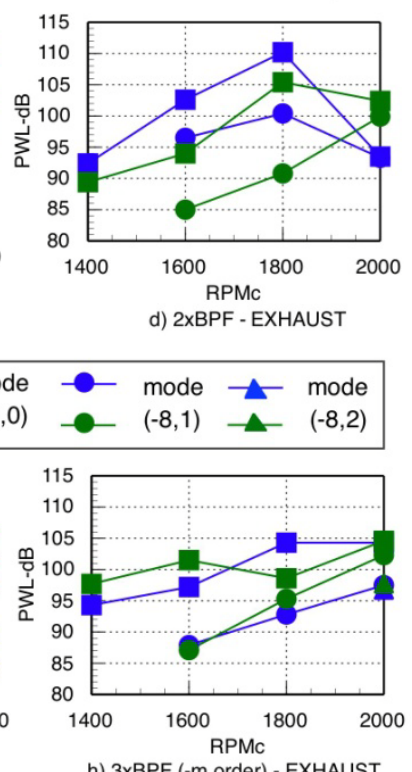

h) 3xBPF (-m order) - EXHAUST d) $2 \times B P F-E X H A U S T$

Figure 17.- R/S interaction modes versus rpm for 14 stator vanes.
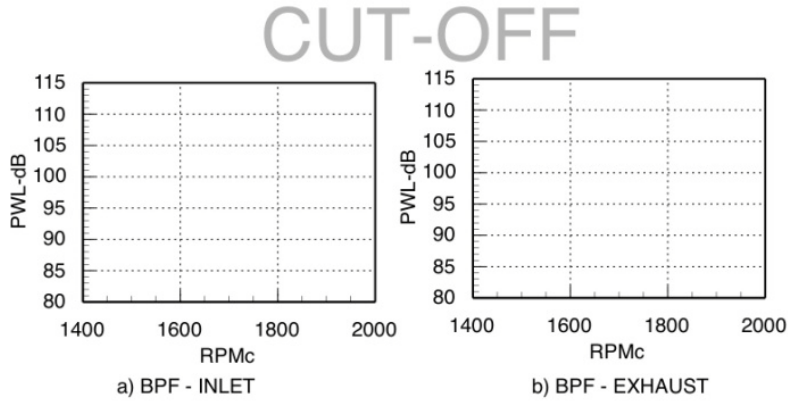

b) BPF - EXHAUST

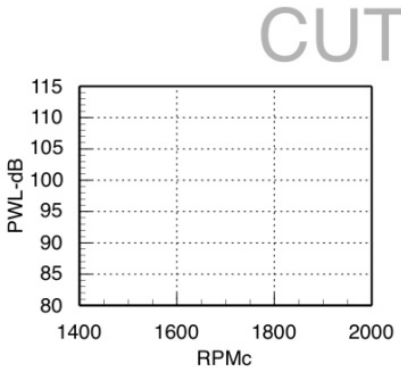

e) 3xBPF (+m order) - INLET

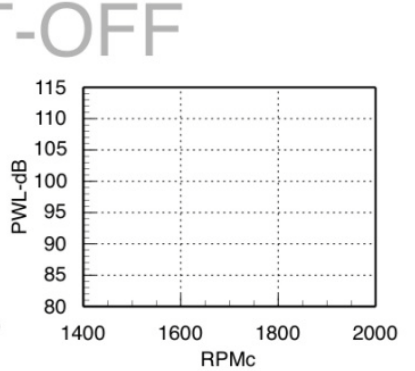

f) 3XBPF (+m order) - EXHAUST

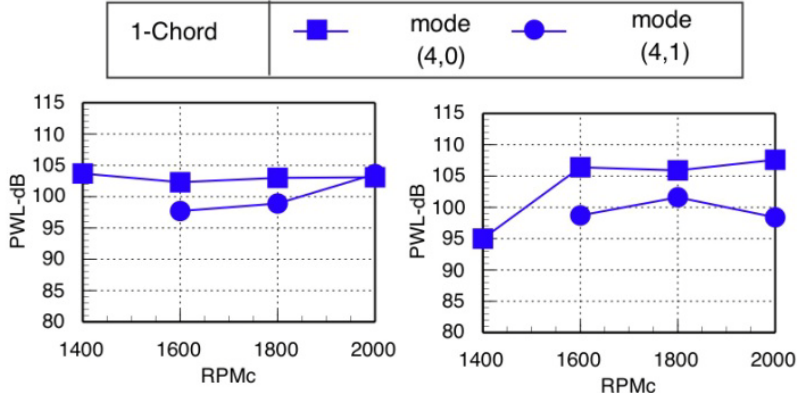

c) 2XBPF - INLET

d) 2XBPF - EXHAUST
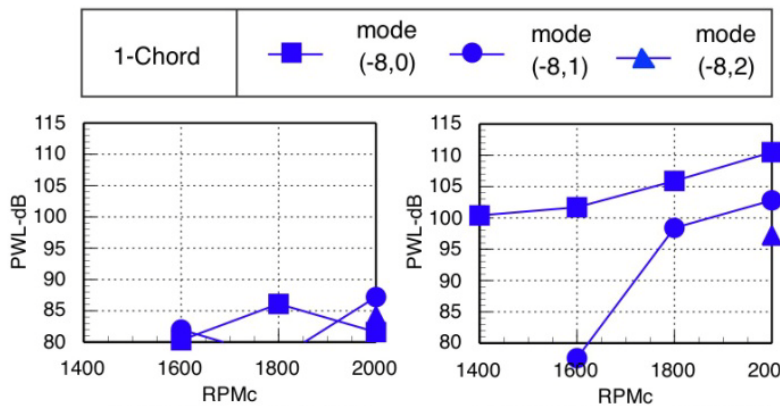

g) $3 \times B P F(-m$ order $)$ INLET

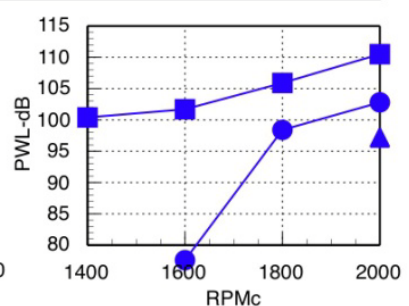

h) 3XBPF (-m order) - EXHAUST

Figure 18.-R/S interaction modes versus rpm for 28 stator vanes. 

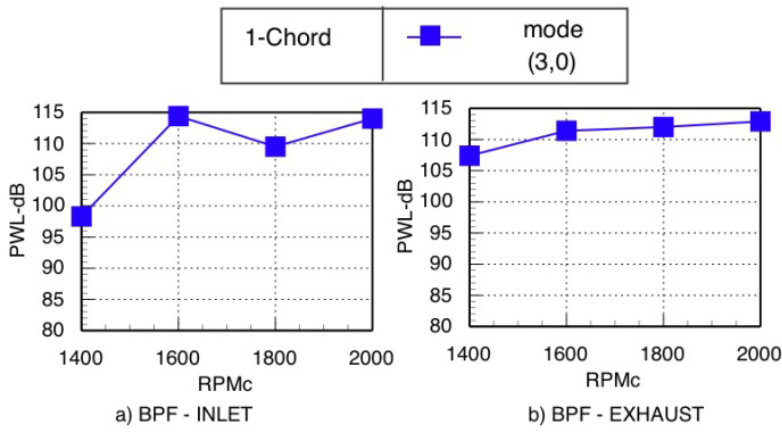

b) BPF - EXHAUST

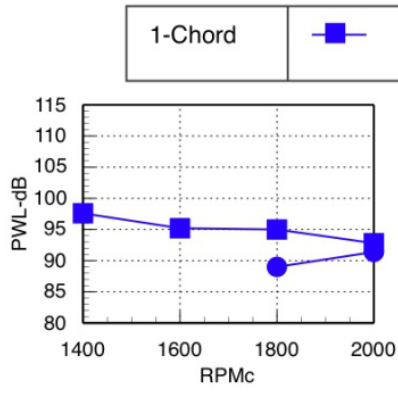

e) 3XBPF (+m order) - INLET
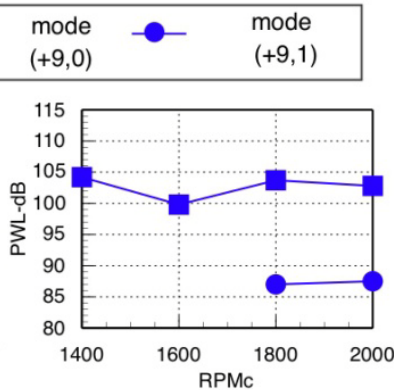

f) 3XBPF (+m order) - EXHAUST

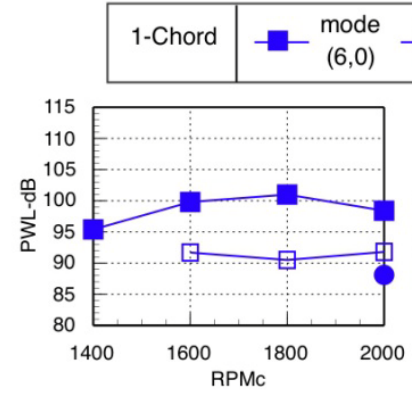

c) 2XBPF - INLET
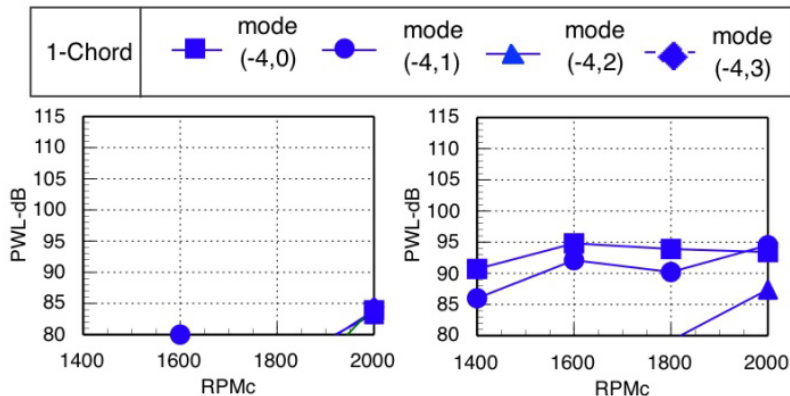

g) $3 \times B P F(-m$ order $)$ - INLET d) 2XBPF - EXHAUST

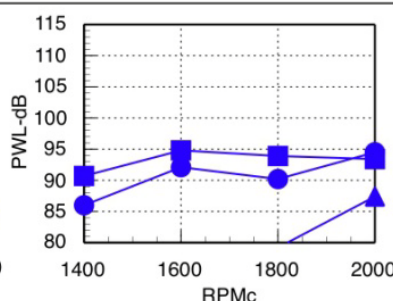

h) 3xBPF (-m order) - EXHAUST

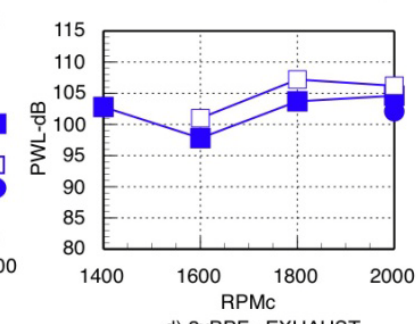

Figure 19.- R/S interaction modes versus $\mathrm{rpm}$ for 13 stator vanes.
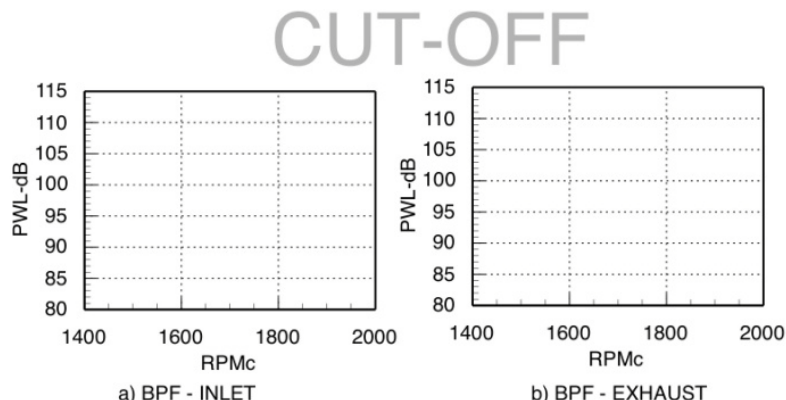

b) BPF - EXHAUST
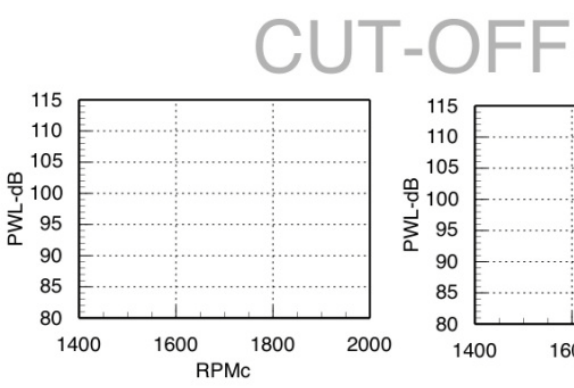

e) $3 \times B P F(+m$ order $)$ INLET

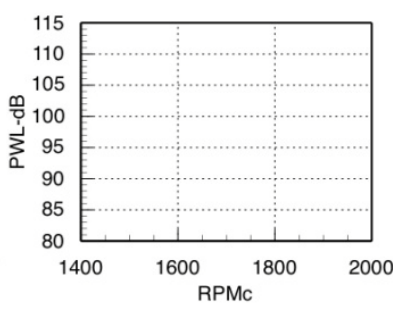

f) 3XBPF (+m order) - EXHAUST

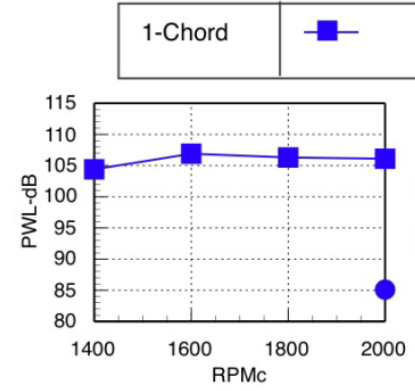

c) 2XBPF - INLET

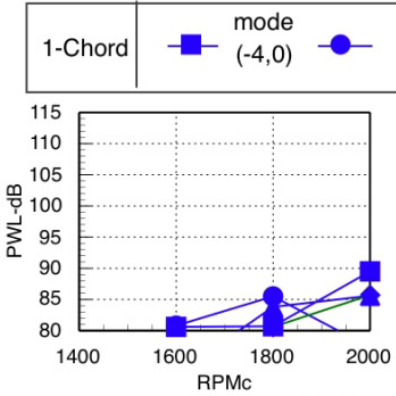

g) 3XBPF (-m order) - INLET
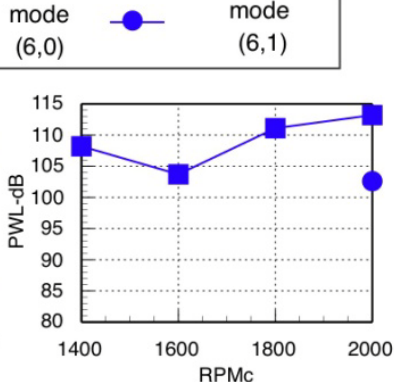

d) 2XBPF - EXHAUST
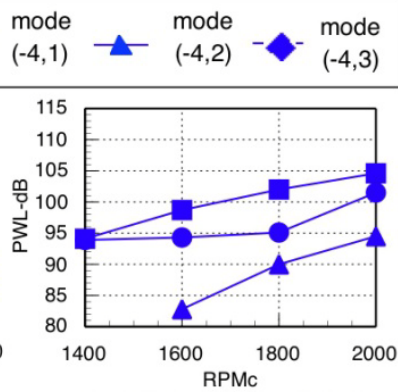

h) 3xBPF (-m order) - EXHAUST

Figure 20.-R/S interaction modes versus rpm for 26 stator vanes. 


\section{Flow Measurements}

\section{Hot-Film Anemometer}

Radial traverses from a two-component axial/circumferential type hot-film probe were acquired at 1-chord length behind the rotor, and from a two-component axial/radial type hot-film in front of the rotor, both traverses performed were at $1800 \mathrm{rpmc}$ fan speed. The hot-film system is a Constant Temperature Anemometer (CTA) type.

The hot-film data was time-domain averaged over 500 fan revolutions using ensembles of one fan revolution and blade passage width. The ensemble-averaged data is then analyzed to determine the blade wake velocity and angle or other pertinent information. The ensemble-averaged data can be subtracted from the original time history to obtain the turbulent velocity and angle. Figure 21 depicts this process. In addition, for configurations with varying temperature across the passage, the dual over-heat technique whereby hot-film data are acquired from two-traverses at different overheat ratios can be used. The data sets can then be iterated to get an estimate of the temperature profile, as well as a more accurate estimate of the velocity which for CTA is very sensitive to temperature. An illustrative example of this is shown in Figure 22 for informational purposes only. This technique was not used herein.

Figure 23 presents the mean radial profiles for 0- and 14-vane configurations. For the inlet, the mean flow velocity is shown in Figure 23(a) and the mean radial flow angle in Figure 23(b). For the exhaust, the mean flow velocity is in Figure 23(c) and the mean circumferential flow angle in Figure 23(d).

Figure 24 shows the parameters averaged for one passage behind the rotor ( 0 stator-vanes installed). The passage flow velocity at each radial location was divided by the mean flow velocity at that radial location, in order to highlight the circumferential variations. Figure 24(a) shows the axial flow velocity, Figure 24(b) the mean flow angle, Figure 24(c) the turbulent flow velocity, and Figure 24(d) the turbulent flow angle, behind the rotor. The profiles show distinct wakes and tip vortices.

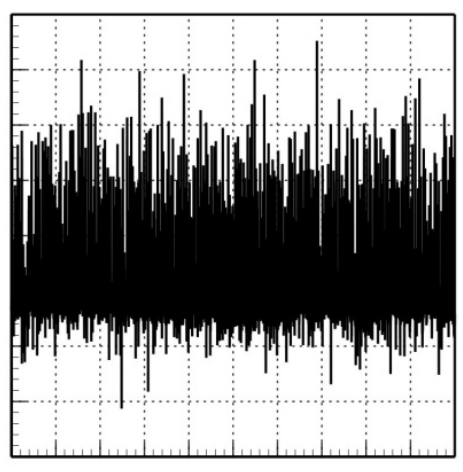

a) Total Time History

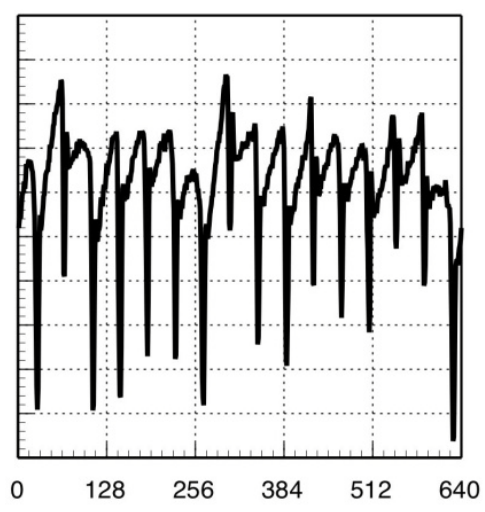

b) Ensemble Averaged over 1 Revolution

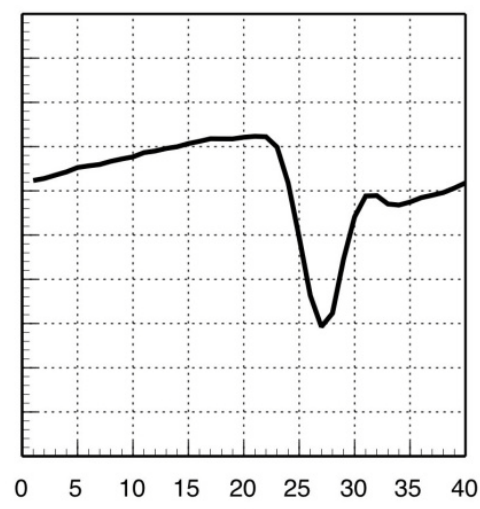

c) Ensemble Averaged over 1 Passage

Figure 21.-Ensemble averaging of hot-film traverse.
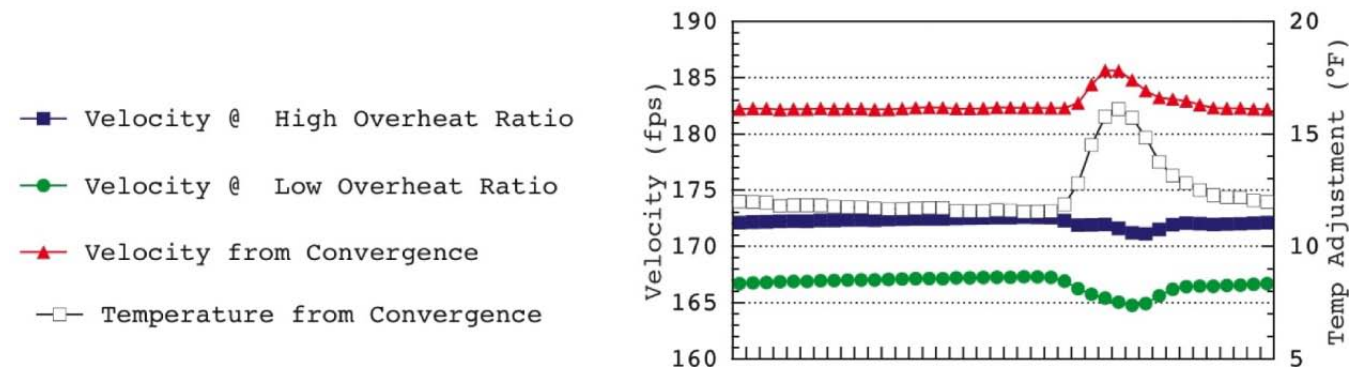

Figure 22.- Hot-film dual overheat ratio technique. 


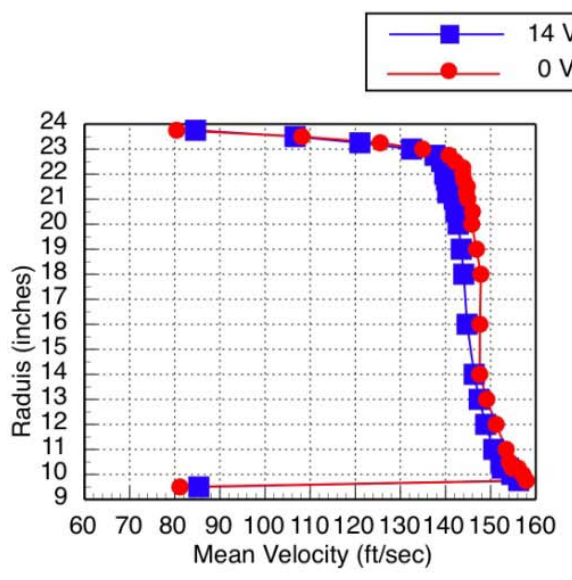

a) Inlet Velocity Profile

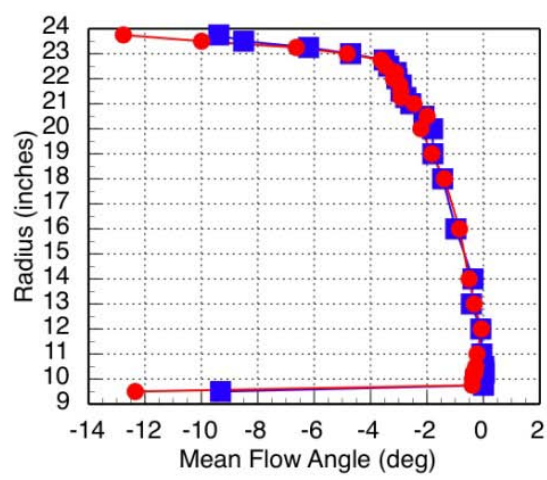

b) Inlet Angle Profile

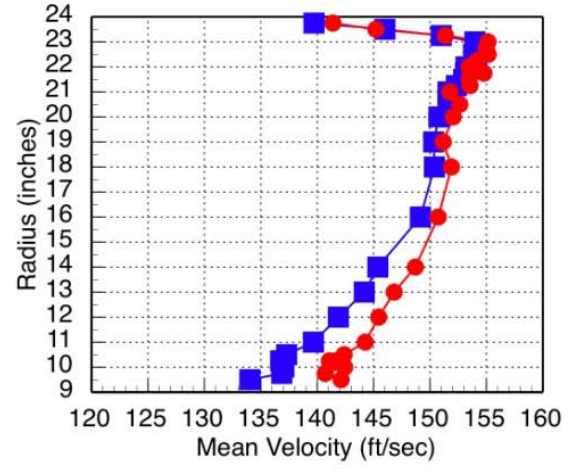

c) Exhaust Velocity Profile

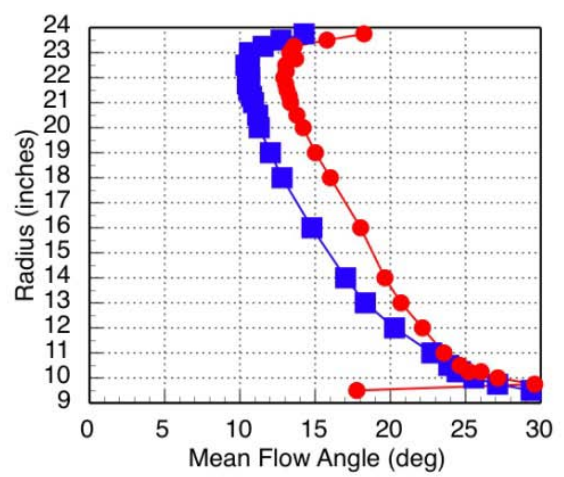

d) Exhaust Flow Angle Profile

Figure 23.-Two-component hot-film traverses.

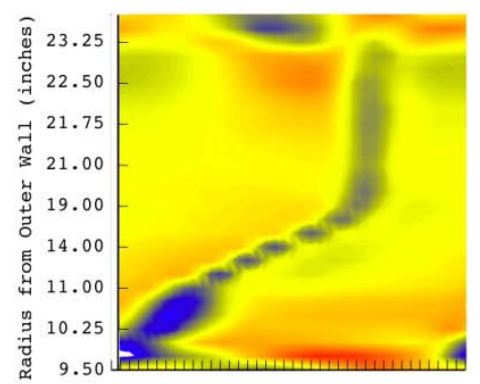

(a) Mean Flow Velocity

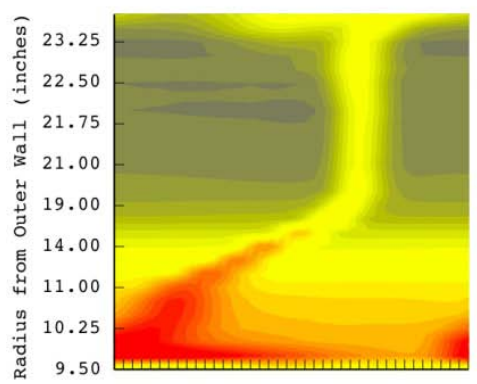

(b) Mean Flow Angle

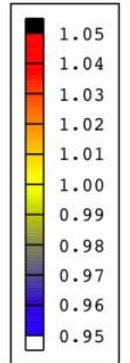

v/Vang

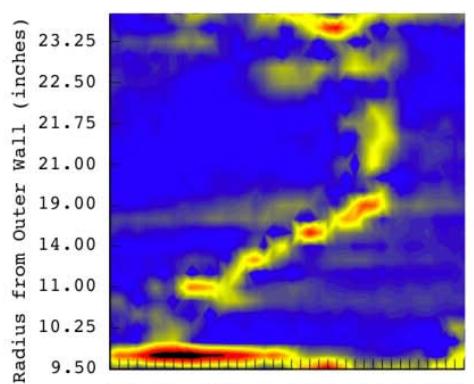

(c) Turbulent FLow Velocity

$\longrightarrow$

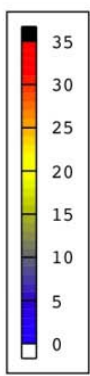

(deg)

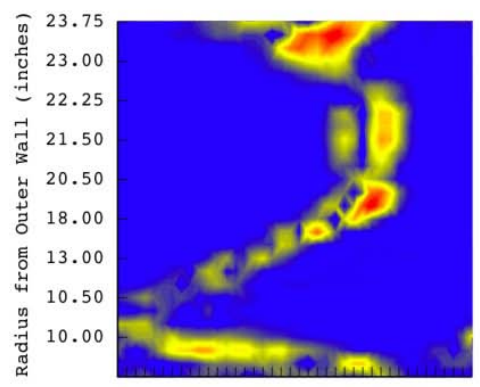

(d) Turbulent Flow Angle

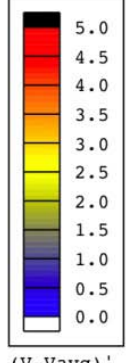

(V-Vavg)
(fps)

Figure 24.-Two-component hot-film traverse behind rotor. 


\section{Stator Vane Unsteady Surface Pressures}

Time histories were acquired from microphones flush mounted in the surface of one stator vane. Three chord lines and one span line were instrumented. Both the suction and pressure sides were instrumented and acquired simultaneously. The location of these microphones is shown in Figure 25. The unsteady surface pressures were acquired at $1800 \mathrm{rpmc}$ with the stator vane positioned at 1/2- and 1-chord; though the leading edge tip microphones tended to clip when the vane was at the 1/2-chord position.

The data are processed in harmonic band decomposition a manner similar to that of the farfield, without the area weighting. The data can also be processed in passage format similar to the hot-film. Figure 26 presents the BPF tone levels on the 3 span wise lines and Figure 27 the chord-wise BPF tone levels. In each plot (a) and (b) present the magnitude of suction and pressure sides while (c) and (d) the phase of suction and pressure sides, respectively. The 2BPF tonal signal distributions are shown in Figures 28 and 29, and the 3BPF in Figures 30 and 31.

The magnitude of broadband signal distributions are plotted in Figures 32 to 34 for the 1st three harmonic bands. The span-wise distributions for the suction and pressure sides are in (a) and (b) while the chord-wise line is shown in (c) and (d).

+ nominal location of unsteady pressure on primary vane at $10 \% 20$ \% 30 응 $40 \% 50 \% 60 \% 70 \% 85 \%$ chord

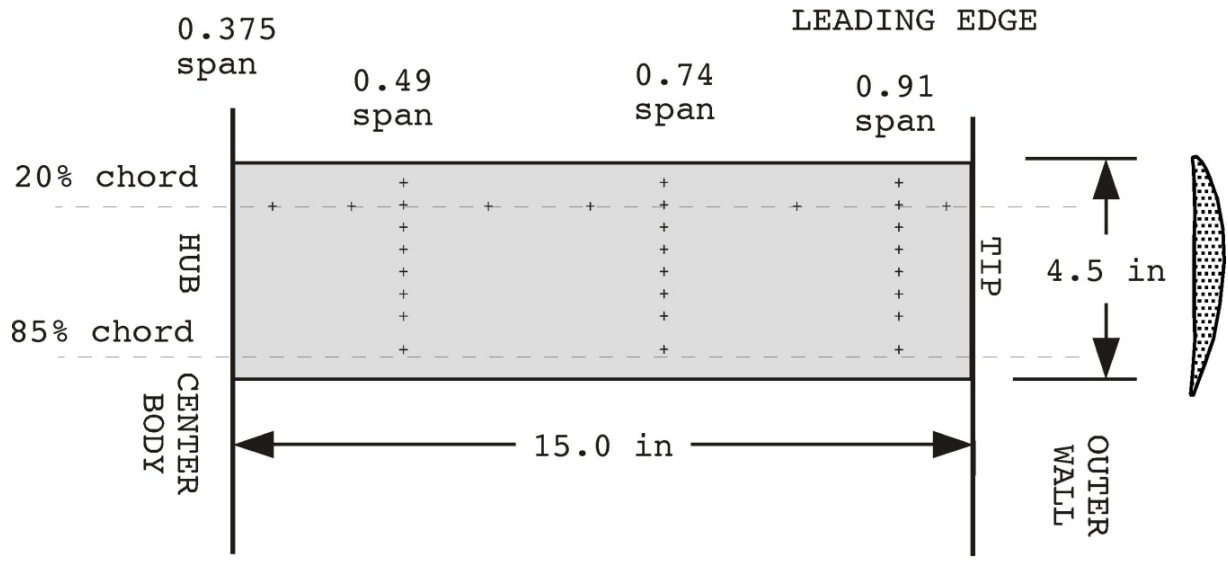

Figure 25.-Location of unsteady pressure taps on stator vane surface. 


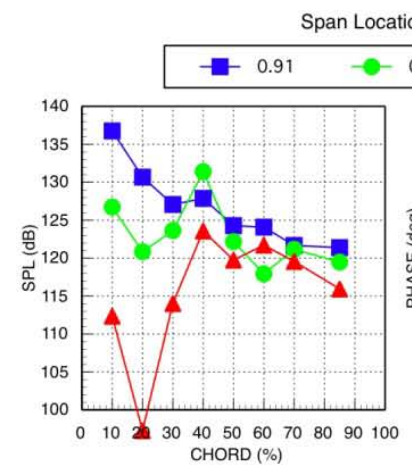

a) Suction Side - Magnitude

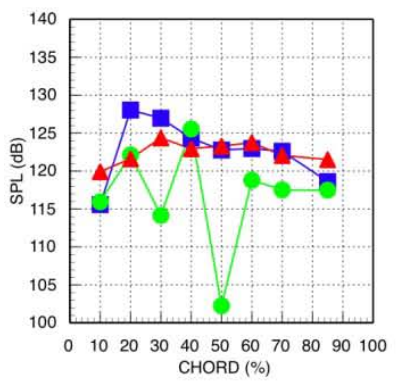

b) Pressure Side - Magnitude

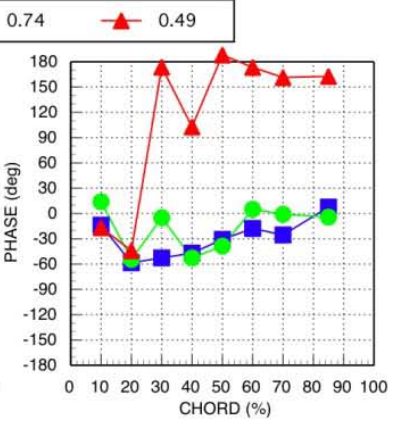

c) Suction Side - Phase

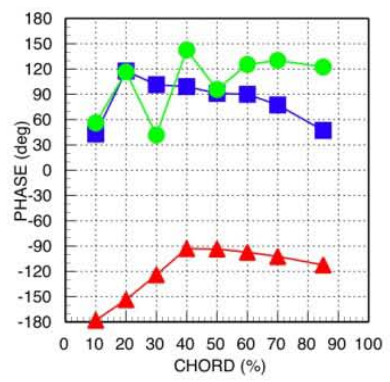

d) Pressure Side - Phase

Figure 26.-BPF tonal unsteady vane pressures along 3 chords.

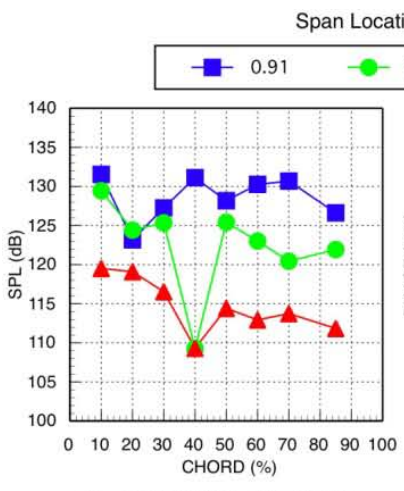

a) Suction Side - Magnitude

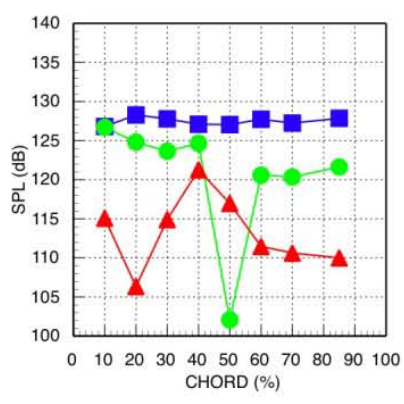

b) Pressure Side - Magnitude

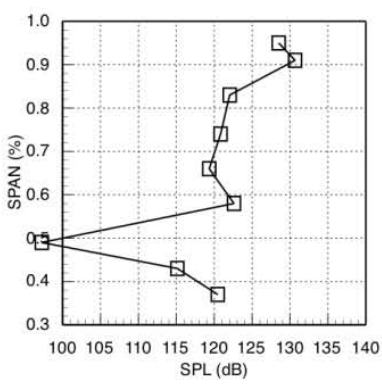

a) Suction Side - Magnitude

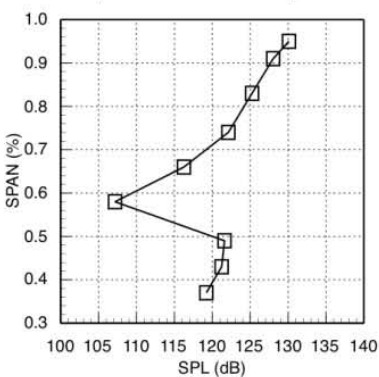

b) Pressure Side - Magnitude

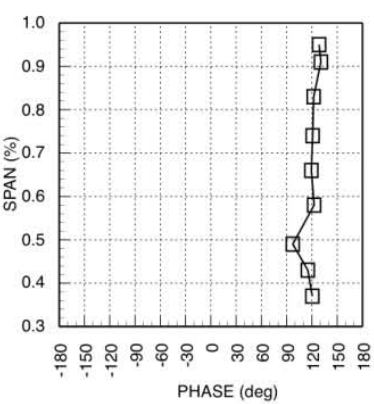

c) Suction Side - Phas

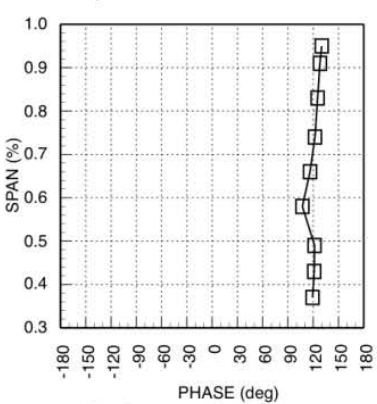

d) Pressure Side - Phase

Figure 27.-BPF tonal unsteady vane pressures along 20 percent span.

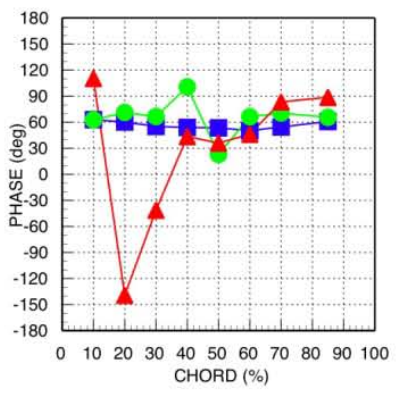

d) Pressure Side - Phase

Figure 28.-2BPF tonal unsteady vane pressures along 3 chords.

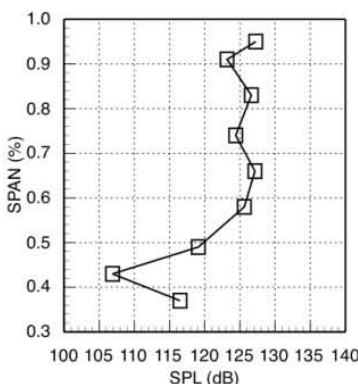

a) Suction Side - Magnitude

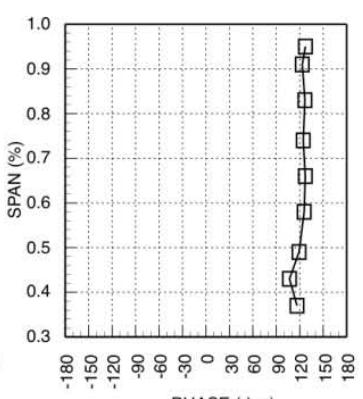

PHASE (deg)

c) Suction Side - Phase

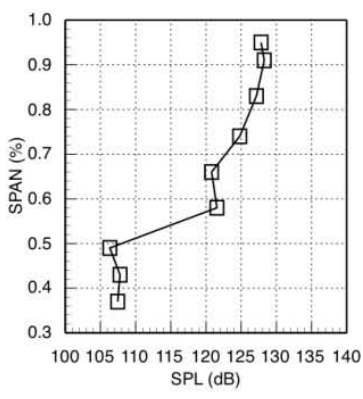

b) Pressure Side - Magnitude

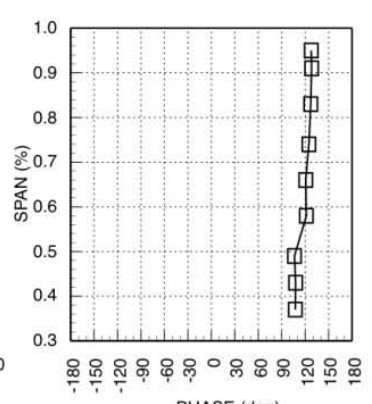

PHASE (deg)

d) Pressure Side - Phase

Figure 29._-2BPF tonal unsteady vane pressures along 20 percent span. 


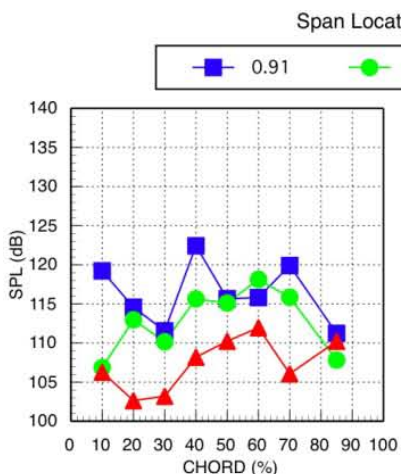

CHORD (\%)

a) Suction Side - Magnitude

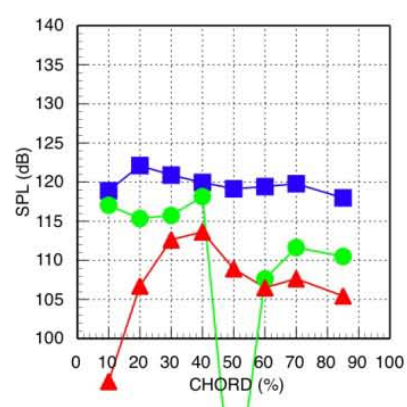

b) Pressure Side - Magnitude

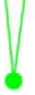

Figure 30.-3BPF tonal unsteady vane pressures along 3 chords.
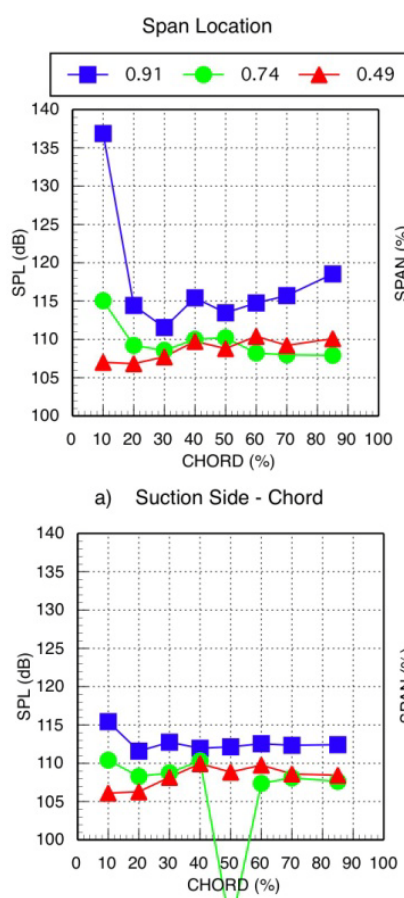

b) Pressure Side - Chord a) Suction Side - Chord

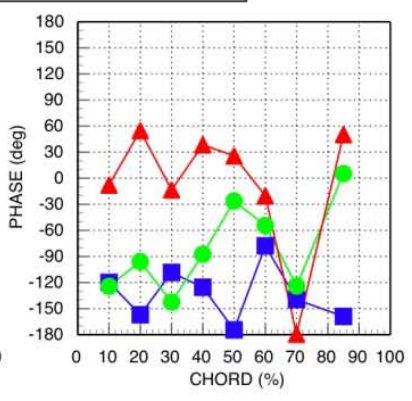

c) Suction Side - Phase

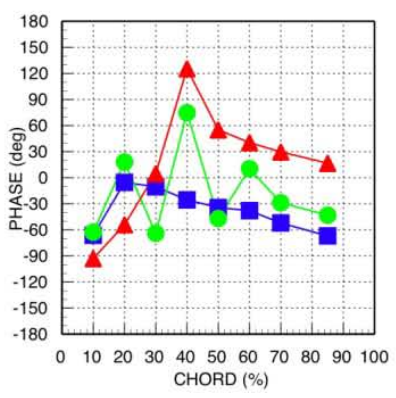

d) Pressure Side - Phase

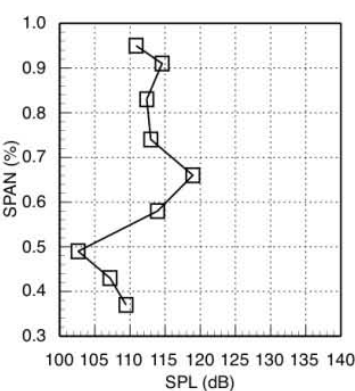

a) Suction Side - Magnitude

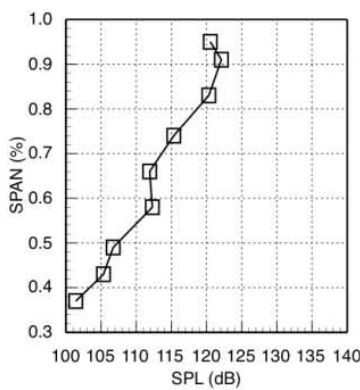

b) Pressure Side - Magnitude

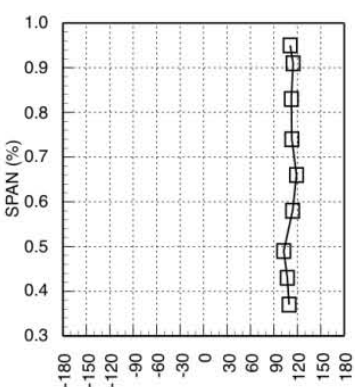

PHASE (deg)

c) Suction Side - Phase

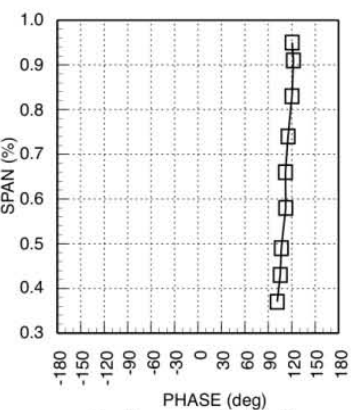

d) Pressure Side - Phase
Figure 31.-3BPF tonal unsteady vane pressures along 20 percent span.

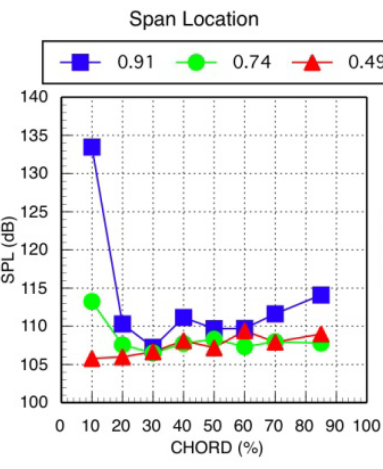

a) Suction Side - Chord

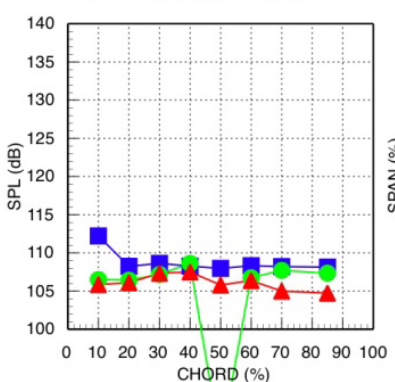

b) Pressure Side - Chord

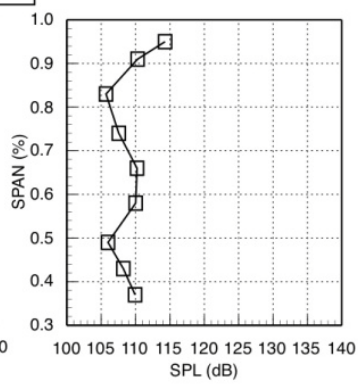

c) Suction Side - Span

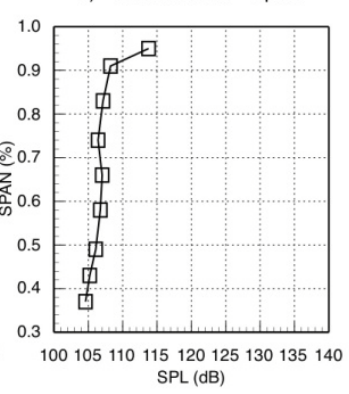

d) Pressure Side - Span d) Pressure Side - Span

Figure 32.-BPF BB unsteady vane pressures.

Figure 33.-2BPF BB Unsteady vane pressures. 


\section{Steady Pressure}

Radial traverses of total and static pressure behind the rotor were acquired. The inlet traverses were 1-chord in front of the rotor while the exhaust traverses where located 1-chord behind the rotor. The static probe has a goose-neck, therefore the static pressure measurement location is actually 2 in. upstream of the total pressure measurement location. Since the rotor untwists, and the traverse path remains perpendicular to the wall, the actual distance between the rotor trailing edge and probe is reduced with immersion. As a result, the radial traverse immersion was limited to prevent blade contact. The pressures from the traverses (all relative to atmosphere) are shown in Figure 35 with 0 and 14 vanes installed. Since the vanes decrease the flow area, a decrease in the static pressure indicates the flow has been accelerated.

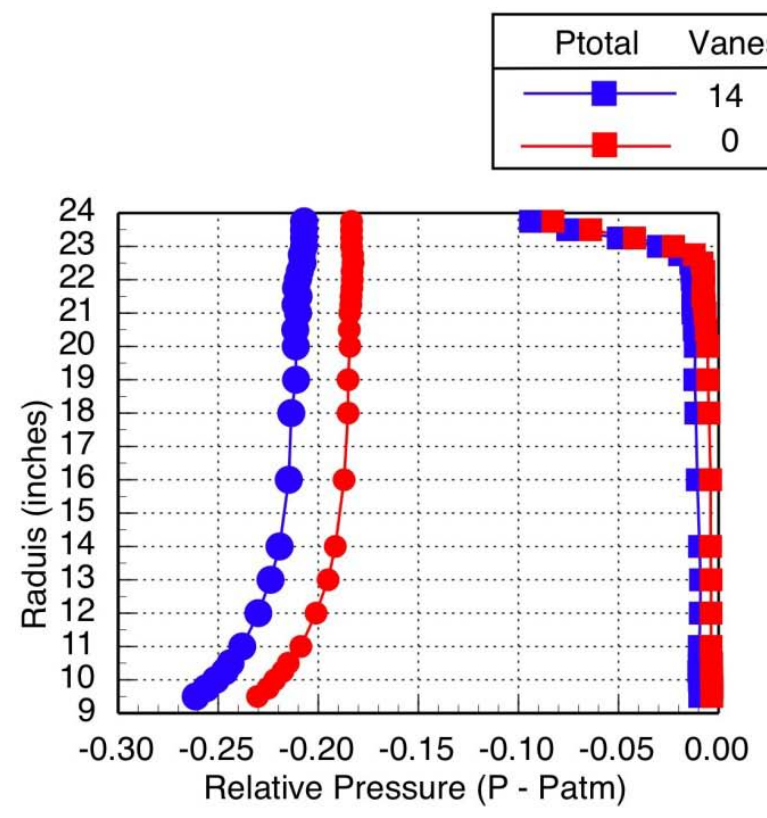

a) Inlet Velocity Profile

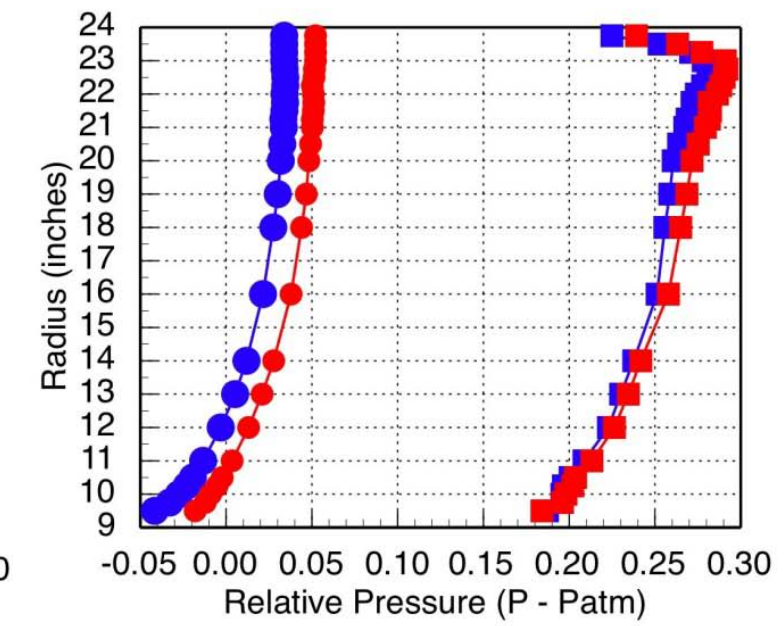

b) Exhaust Velocity Profile

Figure 35.- Steady pressure in front of and behind rotor.

\section{Conclusions}

The Advanced Noise Control Fan is a highly configurable 4-foot diameter low-speed fan that can be used for a variety of research purposes. The ANCF recently underwent a series of upgrades. An updated acoustic and aerodynamic-flow database has been presented that describes the entire aeroacoustic process from generation to farfield observation as depicted in the Appendix. This database can be provided upon request. 


\section{Appendix}

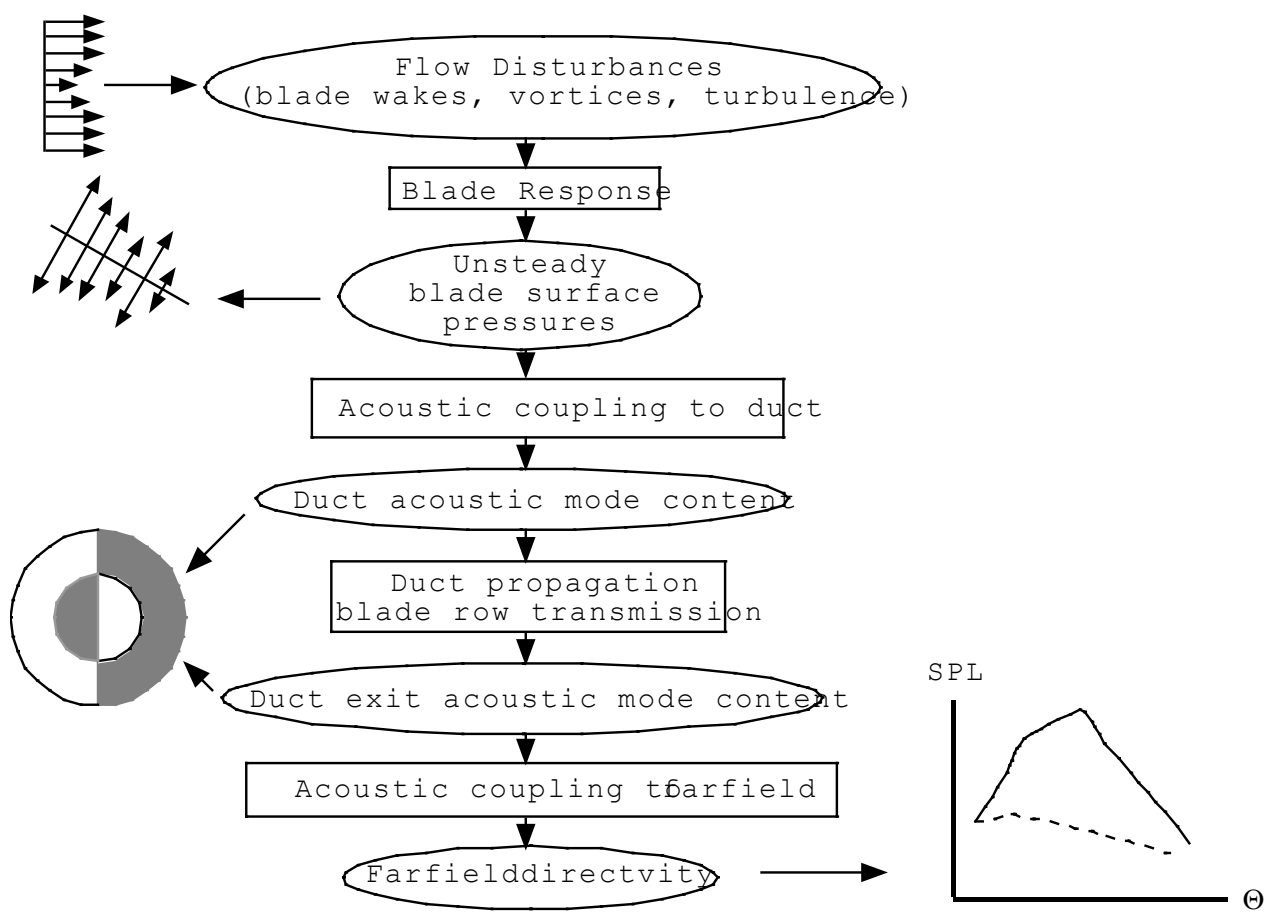

OVALS: Physically measurable quantity.

RECTANGLES: transfer function that can be investigated for noise reduction or code verification.

Figure A1.-Flow chart showing aeroacoustics physics and measurement philosophy. 


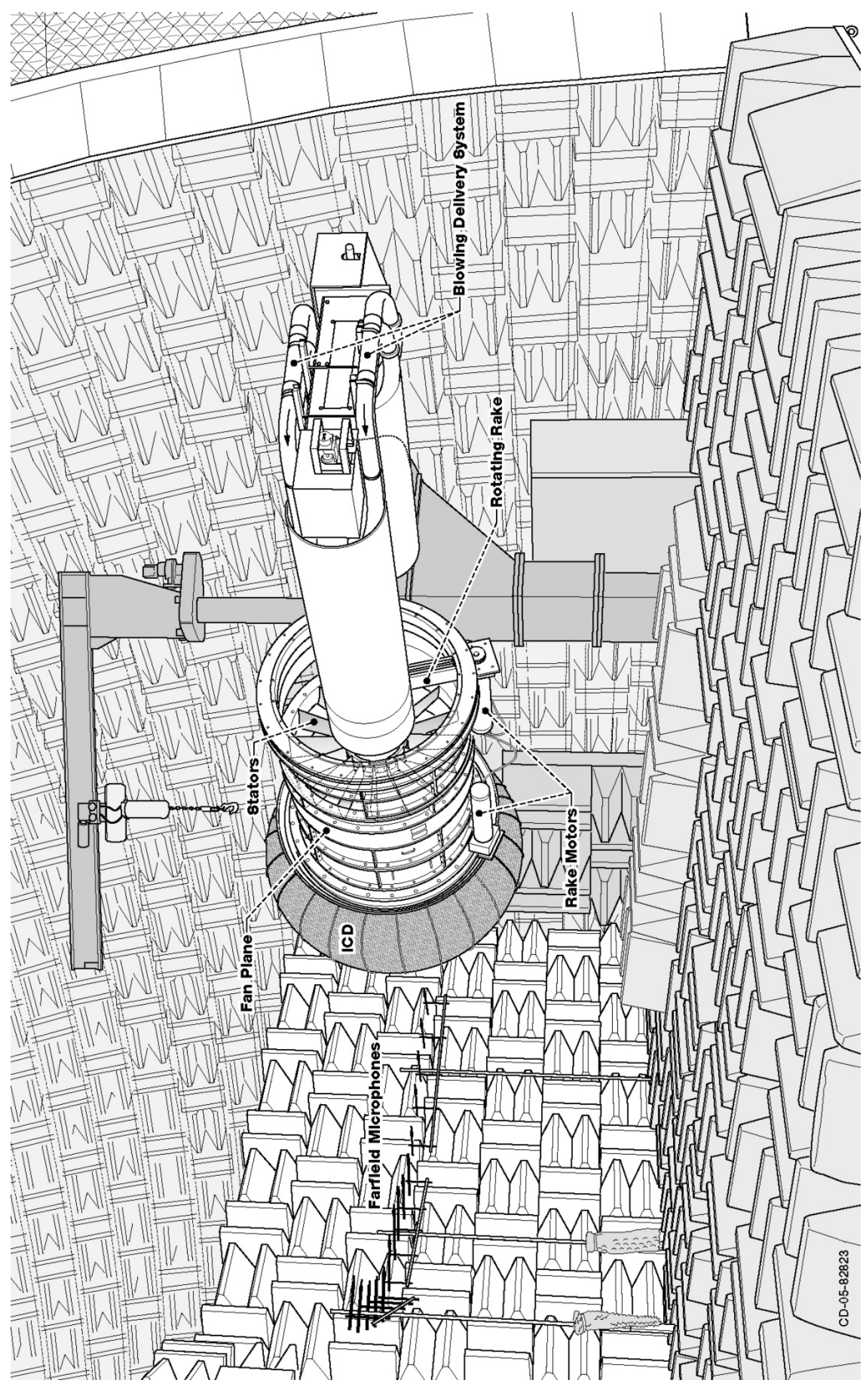

Figure A2.-Three-dimensional line drawing of Advanced Noise Control Fan (ANCF) in the Aeroacoustic Propulsion Laboratory (AAPL). 


\section{References}

1. Hubbard, H.H., editor, Aeroacoustics of Flight Vehicles: Theory and Practice: Volume 1, NASA Reference Publication 1258, Vol. 1, WRDC Technical Report 90-3052.

2. Loew, R.A., Lauer, J.T., McAllister, J., and Sutliff, D.L., "The Advanced Noise Control Fan," NASA/TM-2006-214368, also AIAA-2006-3150, Nov 2006.

3. Heidelberg, L.J., Hall, D.G., Bridges, J.E., and Nallasamy, N., "A Unique Ducted Fan Test Bed for Active Noise Control and Aeroacoustics Research," NASA TM-107213, also AIAA-96-1740.

4. Sutliff, D.L., Nallasamy, N., and Elliott, D.M., "Baseline Acoustic Levels of the NASA Active Noise Control Fan Rig," NASA TM-107214, also AIAA-96-107214.

5. Cooper, B.A., "A Large Hemi-Anechoic Chamber Enclosure for Community-Compatible Aeroacoustic Testing of Aircraft Propulsion Systems, ” Journal of the Institute of Noise Control Engineering of the USA, Jan/Feb 1994.

6. Sutliff, D.L., "Acoustic Characteristics of the Active Noise Control Fan Located in the Compact Farfield Arena," Technical Progress Report, Contract NAS3-00170, Task Order no. 17, Sest Inc.

7. Sutliff, D.L. "Rotating Rake Turbofan Duct Mode Measurement System," NASA/TM-2005213828, November 2005.

8. Rice, E.J., Heidmann, M.F., Marcus, F., and Sofrin T.G., "Modal Propagation Angles in a Cylindrical Duct with Flow and their Relation to Sound Radiation," NASA TM-70930, also AIAA 79-0183.

9. Tyler J.M., and Sofrin T.G., "Axial Flow Compressor Noise Studies," SAE Transactions, Vol. 70, 1962, pp. 309-332.

10. Heidelberg, L.J., and Hall, D.G., "Inlet Acoustic Mode Measurements Using a Continuously Rotating Rake,” Journal of Aircraft, pp. 761-767, July-August 1995. 


\begin{tabular}{|c|c|c|c|c|c|}
\hline \multicolumn{5}{|c|}{ REPORT DOCUMENTATION PAGE } & $\begin{array}{l}\text { Form Approved } \\
\text { OMB No. 0704-0188 }\end{array}$ \\
\hline \multicolumn{6}{|c|}{$\begin{array}{l}\text { The public reporting burden for this collection of information is estimated to average } 1 \text { hour per response, including the time for reviewing instructions, searching existing data sources, gathering and maintaining the } \\
\text { datata needed, and completing and reviewing the collection of information. Send comments regarding this burden estimate or ann other aspect of this collection of information, including suggestions for reducing this } \\
\text { burden, to Department of Defense, Washington Headquarters Services, Directorate for Information Operations and Reports }(0704-0188), 1215 \text { Jefferson Davis Highway, Suite } 1204 \text {, Arlington, VA } 22202-4302 \text {. } \\
\text { Respondents should be aware that notwithstanding any other provision of law, no person shall be subject to any penalty for failing to comply with a collection of information if it does not display a currently valid OMB } \\
\text { control number. } \\
\text { PLEASE DO NOT RETURN YOUR FORM TO THE ABOVE ADDRESS. }\end{array}$} \\
\hline \multicolumn{2}{|c|}{$\begin{array}{l}\text { 1. REPORT DATE (DD-MM-YYYY) } \\
01-10-2009\end{array}$} & \multicolumn{3}{|c|}{$\begin{array}{l}\text { 2. REPORT TYPE } \\
\text { Technical Memorandum }\end{array}$} & 3. DATES COVERED (From - To) \\
\hline \multirow{3}{*}{\multicolumn{5}{|c|}{$\begin{array}{l}\text { 4. TITLE AND SUBTITLE } \\
\text { The Advanced Noise Control Fan Baseline Measurements }\end{array}$}} & 5a. CONTRACT NUMBER \\
\hline & & & & & 5b. GRANT NUMBER \\
\hline & & & & & 5c. PROGRAM ELEMENT NUMBER \\
\hline \multirow{3}{*}{\multicolumn{5}{|c|}{$\begin{array}{l}\text { 6. AUTHOR(S) } \\
\text { McAllister, Joseph; Loew, Raymond, A.; Lauer, Joel, T.; Sutliff, Daniel, L. }\end{array}$}} & 5d. PROJECT NUMBER \\
\hline & & & & & 5e. TASK NUMBER \\
\hline & & & & & $\begin{array}{l}\text { 5f. WORK UNIT NUMBER } \\
\text { WBS 561581.02.08.03.18.02 }\end{array}$ \\
\hline \multicolumn{5}{|c|}{$\begin{array}{l}\text { 7. PERFORMING ORGANIZATION NAME(S) AND ADDRESS(ES) } \\
\text { National Aeronautics and Space Administration } \\
\text { John H. Glenn Research Center at Lewis Field } \\
\text { Cleveland, Ohio 44135-3191 }\end{array}$} & $\begin{array}{l}\text { 8. PERFORMING ORGANIZATION } \\
\text { REPORT NUMBER } \\
\text { E-16886 }\end{array}$ \\
\hline \multirow{2}{*}{\multicolumn{5}{|c|}{$\begin{array}{l}\text { 9. SPONSORING/MONITORING AGENCY NAME(S) AND ADDRESS(ES) } \\
\text { National Aeronautics and Space Administration } \\
\text { Washington, DC 20546-0001 }\end{array}$}} & $\begin{array}{l}\text { 10. SPONSORING/MONITOR'S } \\
\text { ACRONYM(S) } \\
\text { NASA }\end{array}$ \\
\hline & & & & & $\begin{array}{l}\text { 11. SPONSORING/MONITORING } \\
\text { REPORT NUMBER } \\
\text { NASA/TM-2009-215595; AIAA-2009- } \\
0624\end{array}$ \\
\hline \multicolumn{6}{|c|}{$\begin{array}{l}\text { 12. DISTRIBUTION/AVAILABILITY STATEMENT } \\
\text { Unclassified-Unlimited } \\
\text { Subject Categories: } 02,09 \text {, and } 71 \\
\text { Available electronically at http://gltrs.grc.nasa.gov } \\
\text { This publication is available from the NASA Center for AeroSpace Information, 443-757-5802 }\end{array}$} \\
\hline \multicolumn{6}{|c|}{ 13. SUPPLEMENTARY NOTES } \\
\hline \multirow{2}{*}{\multicolumn{6}{|c|}{$\begin{array}{l}\text { 14. ABSTRACT } \\
\text { The NASA Glenn Research Center's (NASA Glenn) Advanced Noise Control Fan (ANCF) was developed in the early 1990s to provide a } \\
\text { convenient test bed to measure and understand fan-generated acoustics, duct propagation, and radiation to the farfield. As part of a complete } \\
\text { upgrade, current baseline and acoustic measurements were documented. Extensive in-duct, farfield acoustic, and flow field measurements } \\
\text { are reported. This is a follow-on paper to document the operating description of the ANCF. } \\
\text { 15. SUBJECT TERMS } \\
\text { Fan noise; Test }\end{array}$}} \\
\hline & & & & & \\
\hline \multicolumn{3}{|c|}{ 16. SECURITY CLASSIFICATION OF: } & $\begin{array}{l}\text { 17. LIMITATION OF } \\
\text { ABSTRACT }\end{array}$ & $\begin{array}{l}\text { 18. NUMBER } \\
\text { OF }\end{array}$ & $\begin{array}{l}\text { 19a. NAME OF RESPONSIBLE PERSON } \\
\text { STI Help Desk (email:help@sti.nasa.gov) }\end{array}$ \\
\hline $\begin{array}{l}\text { a. REPORT } \\
\text { U }\end{array}$ & $\begin{array}{l}\text { b. ABSTRACT } \\
\text { U }\end{array}$ & $\begin{array}{l}\text { c. THIS } \\
\text { PAGE } \\
\text { U }\end{array}$ & UU & $\begin{array}{l}\text { PAGES } \\
29\end{array}$ & $\begin{array}{l}\text { 19b. TELEPHONE NUMBER (include area code) } \\
443-757-5802\end{array}$ \\
\hline
\end{tabular}


